\title{
Fgf10-Expressing Tanycytes Add New Neurons to the Appetite/Energy-Balance Regulating Centers of the Postnatal and Adult Hypothalamus
}

\author{
Niels Haan, ${ }^{1 \star}$ Timothy Goodman, ${ }^{1 *}$ Alaleh Najdi-Samiei, ${ }^{1}$ Christina M. Stratford, ${ }^{1}$ Ritva Rice, ${ }^{2}$ Elie El Agha, ${ }^{3}$ \\ Saverio Bellusci, ${ }^{3,4}$ and Mohammad K. Hajihosseini ${ }^{1}$ \\ ${ }^{1}$ School of Biological Sciences, University of East Anglia, Norwich, NR4 7TJ, United Kingdom, ${ }^{2}$ Institute of Biotechnology, University of Helsinki, 00790 \\ Helsinki, Finland, ${ }^{3}$ Excellence Cluster Cardio-Pulmonary System (ECCPS), University Justus Liebig, 35392 Giessen, Germany, ${ }^{4}$ Saban Research Institute of \\ Children's Hospital Los Angeles, University of California Los Angeles, Los Angeles, California 90027
}

Increasing evidence suggests that neurogenesis occurs in the postnatal and adult mammalian hypothalamus. However, the identity and location of the putative progenitor cells is under much debate, and little is known about the dynamics of neurogenesis in unchallenged brain. Previously, we postulated that Fibroblast growth factor 10-expressing (Fgf10 ${ }^{+}$) tanycytes constitute a population of progenitor cells in the mouse hypothalamus. Here, we show that $\mathrm{Fgfl}^{+}{ }^{+}$tanycytes express markers of neural stem/progenitor cells, divide late into postnatal life, and can generate both neurons and astrocytes in vivo. Stage-specific lineage-tracing of Fgf10 ${ }^{+}$tanycytes using Fgf10creERT2 mice, reveals robust neurogenesis at postnatal day 28 (P28), lasting as late as P60. Furthermore, we present evidence for amplification of Fgf10-lineage traced neural cells within the hypothalamic parenchyma itself. The neuronal descendants of Fgf10 ${ }^{+}$ tanycytes predominantly populate the arcuate nucleus, a subset of which express the orexigenic neuronal marker, Neuropeptide-Y, and respond to fasting and leptin-induced signaling. These studies provide direct evidence in support of hypothalamic neurogenesis during late postnatal and adult life, and identify Fgf10 ${ }^{+}$tanycytes as a source of parenchymal neurons with putative roles in appetite and energy balance.

\section{Introduction}

Neurogenesis in the adult rodent hippocampal subgranular zone (SGZ) and the subventricular zone (SVZ) of the lateral ventricles is well documented (Zhao et al., 2008; Ming and Song, 2011). There is a growing realization that adult neurogenesis may be more widespread and occur in areas that include the hypothalamus (Gould, 2007; Migaud et al., 2010). However, comparatively little is known about the biology of stem/progenitor cells and the dynamics of neurogenesis in the hypothalamus.

The hypothalamus regulates key homeostatic and neuroendocrine functions. Hypothalamic neurons are arranged within anatomically distinct nuclei, in the flanking parenchyma of the third ventricle (3V). For example, control of food uptake, energy balance, and satiety is collectively controlled by the arcuate, ventromedial, lateral, dorsomedial, and paraventricular nuclei

\footnotetext{
Received May 21, 2012; revised Feb. 26, 2013; accepted March 1, 2013.

Author contributions: M.K.H. designed research; N.H., T.G., A.N.-S., C.M.S., R.R., E.E.A., and M.K.H. performed research; S.B. contributed unpublished reagents/analytic tools; N.H., T.G., A.N.-S., R.R., and M.K.H. analyzed data; M.K.H. wrote the paper

This work was supported by a Wellcome Trust Project Grant (091201/Z/10/Z) to M.K.H. N.H. was supported by a studentship from the Anatomical Society of Great Britain and Ireland. We thank members of Professor Magdalena Gotz's laboratory for providing brains of tamoxifen-induced GLAST-creERT2:R26GFP mice, and Professor Rhona Mirsky for critical reading of this manuscript.

The authors declare no competing financial interests.

*N.H. and T.G. contributed equally to this work.

Correspondence should be addressed to Dr. Mohammad K. Hajihosseini, School of Biological Sciences, University of East Anglia, Norwich, NR4 7TJ, UK. E-mail: m.k.h@uea.ac.uk.

DOI:10.1523/JNEUROSCI.2437-12.2013

Copyright $\odot 2013$ the authors $\quad 0270-6474 / 13 / 336170-11 \$ 15.00 / 0$
}

(Blouet and Schwartz, 2010). The 3V walls are lined dorsally by ciliated S100 $\beta$-expressing ependymal cells (Hajihosseini et al., 2008) and ventrally by nonciliated radial glial-like cells, termed tanycytes, which play important roles in trafficking of ions and metabolites (Rodríguez et al., 2005).

Pioneering studies showed that the postnatal and adult hypothalamus contains neural stem/progenitor cells. Hypothalamic cells can form neurospheres (Xu et al., 2005; Li et al., 2012) or distinct neuronal subtypes in vitro (Markakis et al., 2004). Infusion of neurotrophic factors into the adult $3 \mathrm{~V}$ stimulates cell proliferation and neurogenesis (Pencea et al., 2001; Kokoeva et al., 2005; Xu et al., 2005; Pérez-Martín et al., 2010), with some impact on appetite. Several studies suggest that hypothalamic stem/progenitor cells reside within the parenchymal compartment to account for normal or diet-induced remodeling (McNay et al., 2012), or experimental ablation of parenchymal neurons (Luquet et al., 2005; Pierce and Xu, 2010). By contrast, lineagetracing of tanycytes soon after birth, shows that they generate mostly neurons of the median eminence (Lee et al., 2012). However, the potential of tanycytes and their putative contribution to parenchymal neurons at later stages has not been directly tested, and so our understanding of adult hypothalamic neurogenesis is incomplete.

FGFs are a 22-member strong family of signaling molecules with pleiotropic functions in diverse developmental, physiological, and pathological processes (Hajihosseini, 2008; Itoh and Ornitz, 2011). In the CNS, FGFs can regulate areal patterning and lamination of the cerebral cortex (Hasegawa et al., 2004; Toyoda et al., 2010), the formation of oligodendrocytes (Furusho et al., 
2011), and synaptogenesis (Terauchi et al., 2010). Fgf10 maintains stem/progenitor cell function in several non-neural tissues (Mailleux et al., 2005; Yokohama-Tamaki et al., 2006; Nyeng et al., 2007) and transiently regulates cortical radial glial cell formation (Sahara and O'Leary, 2009). However, the perinatal death of Fgf10-deficient mice has precluded an understanding of the postnatal function/s of Fgf10 (Min et al., 1998).

Our previous gene expression studies suggested that Fgf10 ${ }^{+}$ tanycytes constitute a population of neural stem/progenitors (Hajihosseini et al., 2008). Here, we have tested this hypothesis and measured their contribution to hypothalamic neurogenesis during late postnatal life and early adulthood, in vivo. We find that Fgf10 ${ }^{+}$ tanycytes resemble neural stem/progenitors and can divide and generate parenchymal neurons and glial cells in vivo. Stage-specific lineage tracing from P28 and beyond using a novel Fgf10-creERT2 line demonstrates that Fgf10-expressing tanycytes, and possibly also their parenchymal descendants, continually add new neurons to the appetite/energy balance regulating nuclei.

\section{Materials and Methods}

Animal breeding, substance administration, tissue isolation, and processing

Fgf10 $0^{\text {nlacZ/+ }}$ reporter mice carrying a nuclear-targeted lacZ insertion that does not disrupt the coding exons of Fgf10, were described previously (Kelly et al., 2001; Hajihosseini et al., 2008). To lineage-trace $\mathrm{Fgfl}^{+}$cells, Fgf10 ${ }^{\mathrm{CreERT} 2 /+}$ mice carrying a knock-in CreERT2IRES-YFP cassette in exon 1 were used (see Fig. 6A) (El Agha et al., 2012). These mice have no overt phenotype. They were crossed with either ROSA26 $6^{\text {loxP-STOP-LoxP-lacZ }}$ or ROSA26 loxP-STOP-LoxP-Tomato reporter strains (The Jackson Laboratory, here on referred to as R2 $6^{\mathrm{LacZ}}$ and R26 $6^{\text {Tom }}$ ) to create Fgf10 ${ }^{\text {CreERT2 }}$ :R26 $6^{\text {lacZ }}$ or Fgf10 ${ }^{\text {CreERT2 }}$ :R2 $6^{\text {Tom }}$ doubletransgenics, which present no overt phenotypes. Mice were genotyped using a Roche Expand-PCR kit and genomic DNA isolated from tail biopsies. Fgf10 ${ }^{\text {CreERT2 }}$ allele was detected as a 550 base pair (bp) product distinguishing it from wild-type (300 bp) using three primers: P1 (5' AGCAGGTCTT ACCCTTCCAGTATGTTCC-3'), P2 (5'-CTCCTTGGAGGTGATTGTAG CTCCG- $\left.3^{\prime}\right)$, and P3 (5'-TCCATGAGTGAACGAACCTGGTCG- $\left.3^{\prime}\right)$, whose positions are noted in Figure $6 A$. Separately, the R2 ${ }^{\text {lac }}$ allele was distinguished by a $301 \mathrm{bp}$ PCR product from wild-type (209 bp) using three primers: P4 (5'-AAGACCGCGAAGAGTTTGTC-3'), P5 (5'-TAAGCCTG CCCAGAAGACTCC-3'), and P6 (5'-AAGGGAGCTGCAGTGGAG TA-3'). The R $26^{\text {Tom }}$ allele was distinguished by a $196 \mathrm{bp}$ PCR product from wild-type (297 bp), using four primers recommended by The Jackson Laboratory (www.jax.org).

PCR cycles were as follows: (1) Fgf $10^{\text {creERT2 }}: 1$ cycle of: $94^{\circ} \mathrm{C}, 2 \mathrm{~min} ; 10$ cycles of: $94^{\circ} \mathrm{C}$ for $30 \mathrm{~s}, 61^{\circ} \mathrm{C}$ for $30 \mathrm{~s}, 68^{\circ} \mathrm{C}$ for $160 \mathrm{~s}$, followed by 17 cycles of: $94^{\circ} \mathrm{C}$ for $30 \mathrm{~s}, 61^{\circ} \mathrm{C}$ for $30 \mathrm{~s}, 68^{\circ} \mathrm{C}$ for $160 \mathrm{~s}$ plus a $40 \mathrm{~s}$ increment per cycle, ending with 1 cycle of $68^{\circ} \mathrm{C}$ for 7 min. (2) R2 $6^{\text {lacz }}$ and $\mathrm{R} 26^{\mathrm{Tom}}$, as for Fgf $10^{\text {cre }}$, but with a reduced annealing time of $60^{\circ} \mathrm{C}$ and extension time of $90 \mathrm{~s}$, plus a $20 \mathrm{~s}$ increment per cycle.

Mice of either sex were used throughout these studies. All mice were maintained on a mixed C57BL/6129Ola genetic background and bred under a $12 \mathrm{~h}$ light/dark cycle in accordance with local regulations governing work with transgenic animals.

\section{Tamoxifen, BrdU, and EdU treatments}

5-Bromo-2'-deoxyuridine (BrdU) was applied continuously via drinking water (as $1 \mathrm{mg} / \mathrm{ml}$ solution containing $0.25 \mathrm{mg} / \mathrm{ml}$ glucose) in preference to multiple daily intraperitoneal injections that may be stressful to animals. Fresh BrdU-solution was supplied every $72 \mathrm{~h}$ and the drinking bottles were protected from light. Stability of BrdU in this paradigm was validated by the finding that 3-d-old BrdU solution contains sufficient nucleotide analog to label a significant number of cells in the SGZ and SVZ of wild-type mice $(n=$ 3; data not shown). Due to its high cost, EdU (5-ethynyl-2'-deoxyuridine) was administered only by i.p. at $10 \mathrm{mg} / \mathrm{kg}$ bodyweight.

Tamoxifen was administered either via intraperitoneal injection at $80-100 \mathrm{mg} / \mathrm{kg}$ bodyweight from a stock $20 \mathrm{mg} / \mathrm{ml}$ solution prepared by several hours of mixing at $55^{\circ} \mathrm{C}$ in $10 \%$ ethanol/corn oil, or, via ad libitum supply of chow food pellets supplemented with $0.4 \mathrm{~g}$ tamoxifen citrate per kilogram dry weight (Altromin Spezialfutter).

\section{Acute food deprivation and leptin administration}

Age-matched Fgf10 nlacZ $(n=5)$ and wild-type $(n=5)$ mice, or Tamoxifen-treated Fgf10 ${ }^{\mathrm{CreERT}}$ :R26 ${ }^{\text {Tom }}$ (and the corresponding control mice) were time-matched fed or fasted. On the day of the experiment, fasted mice were food deprived from 10:00 A.M. to 11:00 P.M. (corresponding to $9 \mathrm{~h}$ before and $4 \mathrm{~h}$ into the dark cycle) and were intraperitoneally injected with either vehicle or $100 \mu \mathrm{g} / \mathrm{kg}$ body weight recombinant murine leptin (Peprotech; prepared in $0.1 \%$ BSA), $1 \mathrm{~h}$ before being killed at 11:00 P.M.

\section{Tissue isolation and sectioning}

Animals were killed by $\mathrm{CO}_{2}$ asphyxiation and promptly perfused transcardially with $4 \%$ paraformaldehyde solution (PF; $\mathrm{pH} 7.4$, prepared in PBS). For vibratome sectioning, brains were postfixed in $4 \% \mathrm{PF}$ and dehydrated to absolute ethanol. Just before use, brains were rehydrated back to PBS, embedded in 3\% agar, and sectioned on a Lecia 1200 vibratome at $60 \mu \mathrm{m}$ thickness. For cryostat sections, brains were either postfixed in $4 \% \mathrm{PF}$ and cryoprotected in 30\% sucrose solution for $3 \mathrm{~d}$ before embedding in OCT, or, harvested unfixed and frozen directly into OCT on dry ice and sectioned at $12-20 \mu \mathrm{m}$ on a Leica HM560 freezing microtome. For paraffin sectioning, brains were dehydrated to $70 \%$ ethanol, embedded in paraffin, and sectioned at $10 \mu \mathrm{m}$.

To visualize Fgf10 ${ }^{+}$cells and their descendants, brains of Fgf10 ${ }^{\text {nlacZ }}$ or tamoxifen-treated Fgf10 ${ }^{\mathrm{CreERT} 2}: \mathrm{R} 26^{\text {lacZ }}$ mice were stained with 5-bromo-4-chloro-3-indolyl- $\beta$-D-galactopyranoside (X-gal) immediately after perfusion, by overnight incubation at $37^{\circ} \mathrm{C}$ in a solution containing $0.5 \mu \mathrm{g}$ of Xgal in $2 \mathrm{mM} \mathrm{MgCl}_{2}, 5 \mathrm{mM} \mathrm{K}_{4} \mathrm{Fe}(\mathrm{CN})_{6}$, and $5 \mathrm{~mm}$ $\mathrm{K}_{3} \mathrm{Fe}(\mathrm{CN})_{6}$. Alternatively, brains of Fgf10 ${ }^{\text {nlacZ }}$ or Fgf10 ${ }^{\text {CreERT2 }}: \mathrm{R} 6^{\text {Tom }}$ mice were sectioned, immunolabeled with anti- $\beta$ gal or anti-Tomato (dsRed) antibodies and visualized under U/V light.

\section{Immunohistochemistry and immunofluorescence labeling}

Antibodies. Primary antibodies used were chicken (1:500, Abcam) or rabbit (Millipore 1:1000) anti $\beta$-galactosidase ( $\beta$ gal) antibodies either alone or in conjunction with rabbit anti-BLBP (1:300, Abcam); -dtTomato (dsRed) (1:1000; Clontech); -GFP (1:1000, Abcam); -NPY (1:1000, Stratech); -DARPP32 (1:200, Millipore); -c-Fos (1:50, Calbiochem), or -phospho STAT3 (1:500, New England Biolabs); Mouse antiBrdU (IgG $; 1: 200$, Sigma); -GFAP ( $\operatorname{IgG}_{1}, 1: 800$, Millipore); -Nestin $\left(\operatorname{IgG}_{1}, 1: 50\right.$, DSHB); -Musashi1 ( $\operatorname{IgG}_{1}, 1: 300$, Abcam); -NeuN (IgG 1:1500, Millipore); or -Sox2 (1:50, R\&D Systems). Secondary antibodies of the relevant species and subclass, either coupled to biotin, horseradish peroxidase (HRP), or Alexa fluorochromes $(-350,-488$, or $-568 / 594)$ as well as Streptavidin-coupled to Texas-red or Cy2, were purchased from Invitrogen, Sigma, or Vector Laboratories and used at previously described dilutions (Hajihosseini et al., 2008).

Immunolabeling. To simultaneously permeabilize and block nonspecific binding sites, vibratome-generated sections were incubated in a solution of $20 \%$ normal goat serum (NGS) and 1\% Triton X-100 (TX) in PBS for $2 \mathrm{~h}$ at room temperature (RT). Subsequently, sections were incubated overnight at $4^{\circ} \mathrm{C}$, with primary antibodies diluted in $0.2 \% \mathrm{NGS}$, $0.1 \%$ Triton in PBS. The next day, sections were washed five times ( $1 \mathrm{~h}$ per wash) in $0.2 \%$ NGS, $0.1 \%$ TX in PBS and incubated with secondary antibodies diluted in $0.2 \% \mathrm{NGS}, 0.5 \% \mathrm{NP} 40$ in PBS overnight at $4^{\circ} \mathrm{C}$. The next day, sections were washed six times (30 min each wash) in PBS, counterstained with Hoechst 33258 and mounted in Vectashield (Vector Laboratories). To detect $\mathrm{BrdU}$, sections were pretreated with $1 \mathrm{~m} \mathrm{HCl}$ at $47^{\circ} \mathrm{C}$ for $30 \mathrm{~min}$ before blocking. EdU was visualized by permeabilizing the sections in $0.5 \%$ TX for 30 min followed by a $2 \mathrm{~h}$ incubation at RT in EdU reaction mixture $\left(1 \mathrm{~mm} \mathrm{CuSO}_{4}, 1 \mu \mathrm{m}\right.$ Alexa Fluor azide $488,100 \mathrm{~mm}$ ascorbic acid in $0.1 \mathrm{~m}$ Tris- $\mathrm{HCl}, \mathrm{pH} 8.5)$ before counterstaining and mounting in Vectashield.

Cryostat sections were permeabilized on the slide with a precooled 1:1 mixture of acetone/methanol for $3 \mathrm{~min}$. Nonspecific binding sites were blocked with $10 \% \mathrm{NGS} / 1 \%$ TX in PBS for $1 \mathrm{~h}$ at RT. Primary and secondary antibodies were applied in $0.2 \%$ NGS, $0.1 \%$ TX diluted in PBS, 
either overnight at $4^{\circ} \mathrm{C}$, or for $1 \mathrm{~h}$ at RT. After final washes in PBS, sections were counterstained with Hoechst and mounted. Immunolabeled cells in both vibratome and cryostat-generated sections were imaged as Z-stacks ranging in thickness from 0.5 to 2.0 $\mu \mathrm{m}$ thickness using a Zeiss Axioplan $2 \mathrm{mi}-$ croscope with an Apotome attachment, using Axiovision 4.8 software.

In Xgal-stained brains, cell-type specific markers were visualized by immuno-peroxidase labeling. For this, endogenous peroxidase activity was quenched by a 90 min treatment with $6 \% \mathrm{H}_{2} \mathrm{O}_{2}$ / PBS, before NGS-blocking. After the application of primary and secondary antibodies as described above, sections were washed three times $(20 \mathrm{~min}$ per wash) in $50 \mathrm{~mm}$ Tris/pH 8.0, before carrying out the 3,3'-diaminobezidine (DAB) reaction using a DAB Kit (Vector labs). Xgal/DAB-stained sections were imaged under DIC (Nomarski) using a Zeiss Axiophoto microscope. Image brightness and contrast was optimized using Adobe Photoshop.

\section{In situ hybridization}

In situ hybridization using Digoxygenin (DIG)-labeled Fgf10 cRNA probes was performed after modifications of a protocol used for ${ }^{35}$ S-labeled probes (Hajihosseini et al., 2008). Briefly, paraffin sections were deparaffinized and rehydrated, permeabilized in a boiling solution of $0.01 \mathrm{~m}$ sodium citrate, $\mathrm{pH}$ 6.0 , and washed in $0.5 \%$ SDS before treatment with $0.25 \%$ acetic anhydride in triethanolamine and final dehydration. Sections were incubated with DIG-labeled cRNA probes at $65^{\circ} \mathrm{C}$ overnight. Next day, sections were washed and preblocked according to standard protocols, and incubated overnight at $4^{\circ} \mathrm{C}$ with anti-DIG-AP Fab antibodies (1:2000; Roche). Excess antibody was washed and color developed using a mix of NBT $(70 \mathrm{mg} / \mathrm{ml}) / \mathrm{BCIP}(50 \mathrm{mg} /$ $\mathrm{ml}$ ) solution. Sections were postfixed in $4 \%$ PFA and mounted in aqueous mounting agent.

\section{Cell counts and statistical analysis}

Immunofluorescently labeled cells were counted in three-dimensionally reconstructed images obtained from serial z-stacks $(0.5-2.0 \mu \mathrm{m}$ thickness) of vibratome or cryostat sections under $\times 10$ and $\times 20$ objectives. To avoid double counting, only whole Hoechst-positive nuclei contained within the 3D image were counted. Moreover, for quantifications, only the middle 30 $\mu \mathrm{m}$ of each $60-\mu \mathrm{m}$-thick vibratome section, or every other $12-20-\mu \mathrm{m}$-thick cryostat section, was analyzed. Colocalization of marker antibodies or double labeling of cells was verified by analyzing cut views of $3 \mathrm{D}$ images.

$\mathrm{BrdU}^{+}$and $\mathrm{BrdU}^{+} / \beta \mathrm{gal}^{+}$cells were counted using the manual cell counter option of ImageJ software. The parenchyma was defined as the area contained within $350 \mu \mathrm{m}$ of the third ventricle.

$\mathrm{LacZ}^{+}$cells in Xgal-stained tissues (as in tamoxifen-treated Fgf10 ${ }^{\text {CreERT2}}$ : $\mathrm{R} 26^{\mathrm{lacZ}}$ brains), were quantified by manual inspection of cells at multiple focal planes within the sections.

Random sections were double-counted by two independent workers, one of whom was blind to the experiment, only to discover a margin of error not exceeding $7 \%$.
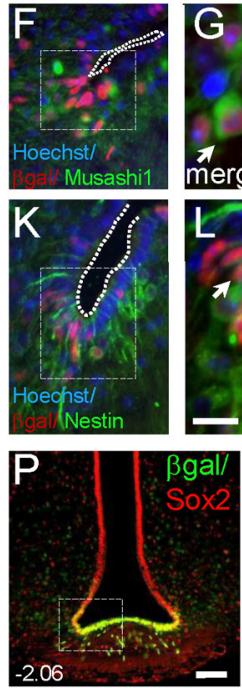
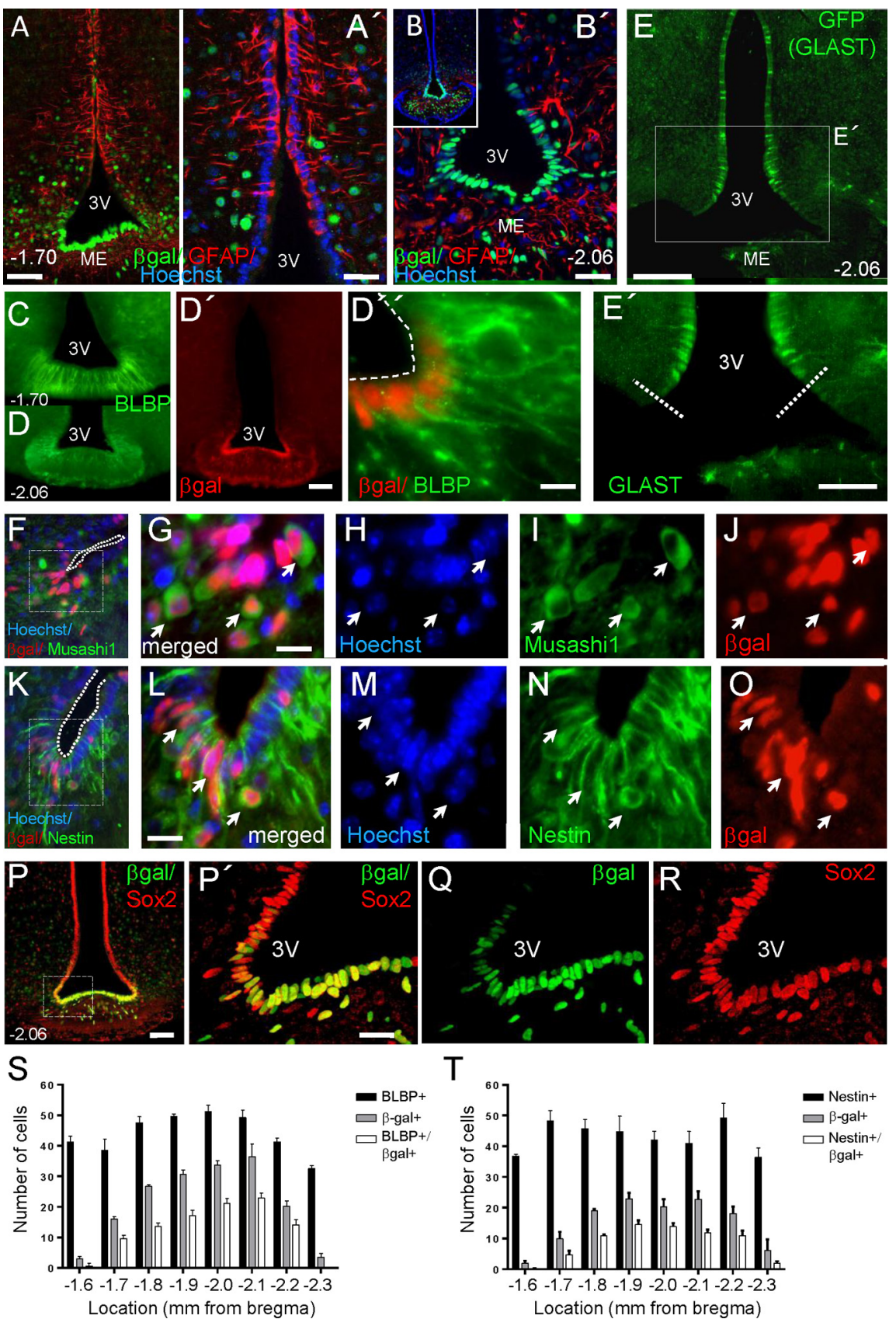

$\mathrm{T}$
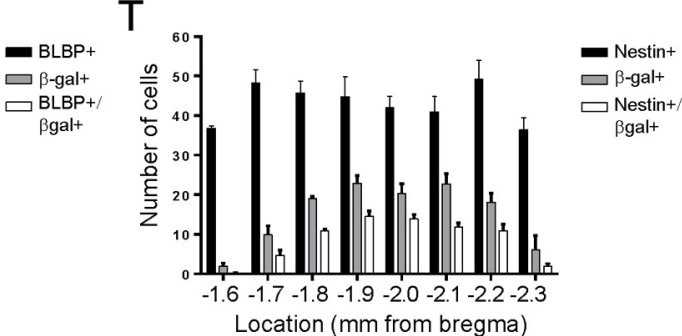

Figure 1. Fgf10 ${ }^{+}$tanycytes express neural stem/progenitor markers and are most abundant in the central regions of the median eminence. Images show coronal vibratome $\left(\boldsymbol{A}-\boldsymbol{E}^{\prime}, \boldsymbol{P}-\boldsymbol{R}\right)$ and cryostat $(\boldsymbol{F}-\mathbf{0})$ sections of P60 Fgf10 ${ }^{\text {nlacz }}$ brains, at the level of ME (bregma -1.70 or -2.06 , as indicated). Fgf10 ${ }^{+}$tanycytes, visualized by anti- $\beta$ gal immunolabeling, coexpress markers of neural stem/progenitor cells: BLBP $\left(\boldsymbol{C}-\boldsymbol{D}^{\prime \prime}\right)$, Musashi1 $(\boldsymbol{F}-\boldsymbol{J})$, nestin $(\boldsymbol{K}-\mathbf{0})$, and Sox2 $(\boldsymbol{P}-\boldsymbol{R})$, but not GFAP $\left(\boldsymbol{A}-\boldsymbol{B}^{\prime}\right)$. Note that expression of Sox2 is not limited to ependymal cells, but also present in some parenchymal cells. $\boldsymbol{E}, \boldsymbol{E}^{\prime}$, Domain of GLAST expression in the 3V ependyma as visualized by anti-GFP immunolabeling of tamoxifen-treated GLAST ${ }^{\text {creERT2 }}$ :R26 ${ }^{\text {GFP }}$ brain. Dashed lines in $\boldsymbol{E}^{\prime}$ show the ventral limit of GLAST expression. S, $I, F g f 10^{+}$tanycytes are more abundant in the central regions of the ME, where only a subpopulation expresses BLBP or nestin. Scale bars: $\boldsymbol{A}, \boldsymbol{B}^{\prime}, \boldsymbol{D}^{\prime}, \boldsymbol{E}, \boldsymbol{P}, 50 \mu \mathrm{m} ; \boldsymbol{A}^{\prime}, \boldsymbol{E}^{\prime}, \boldsymbol{P}^{\prime}, 25 \mu \mathrm{m} ; \boldsymbol{D}^{\prime \prime}, \boldsymbol{G}, \boldsymbol{L}, 10 \mu \mathrm{m}$.

Bregma coordinate of sections was determined by consultation of the mouse brain atlas (Franklin and Paxinos, 2007), taking into consideration the shape and width of the ventricular spaces, the presence of particular hypothalamic nuclei and other brain structures, and, the serial position of the section with respect to other bregma-determined sections.

Significant differences were determined by subjecting the data to Student's $t$ test or one-way ANOVA with Tukey's post hoc test. $p<0.05$ was defined as significant. All statistics were performed using Graphpad Prism software. 

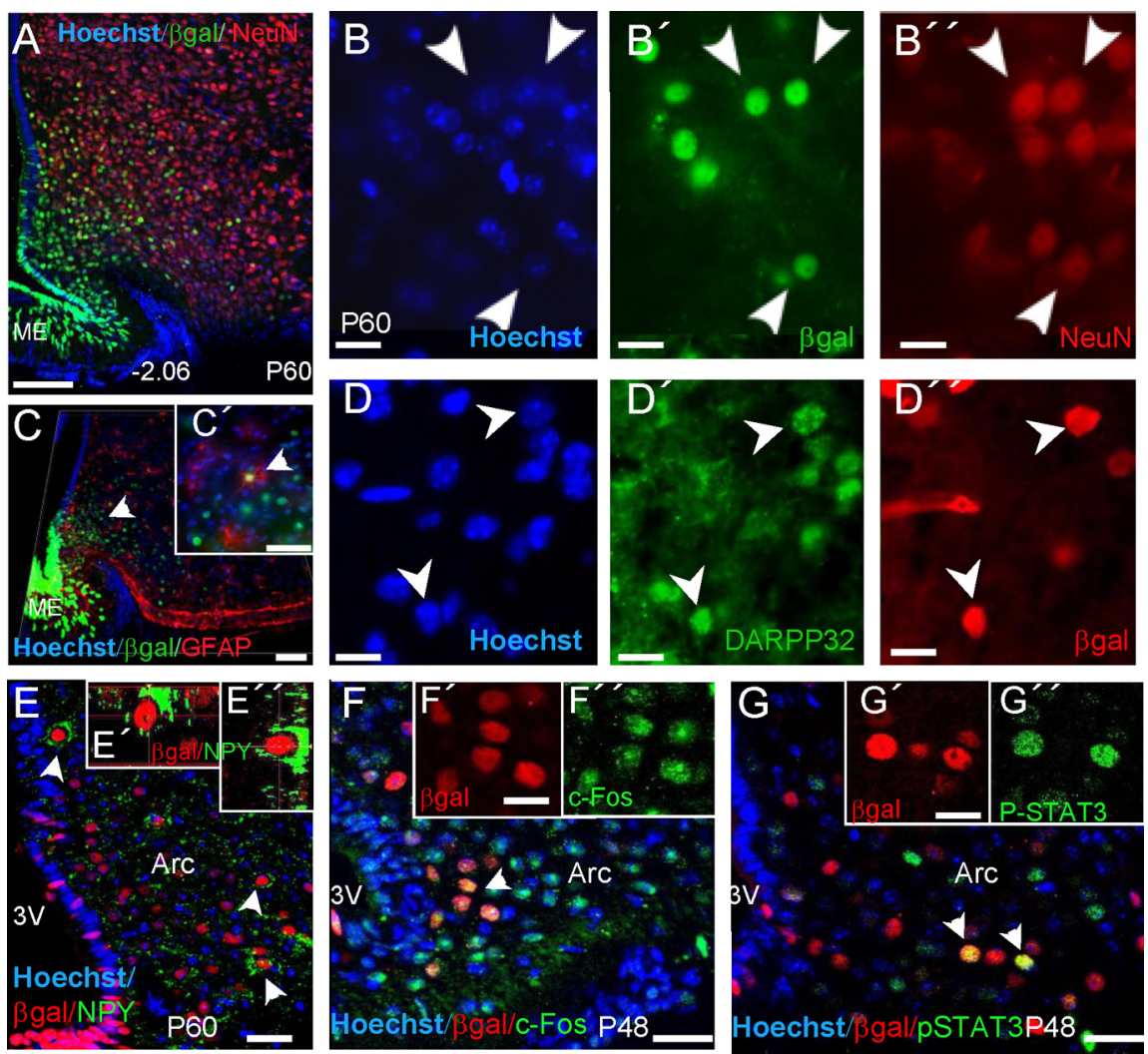

Figure 2. Parenchymal descendants of Fgf $10^{+}$tanycytes express mature neural cell type markers and respond to acute fasting. $\boldsymbol{A}-\boldsymbol{D}^{\prime \prime}$, Expression of NeuN $\left(\boldsymbol{A}-\boldsymbol{B}^{\prime \prime}\right)$, DARPP32 $\left(\boldsymbol{D}-\boldsymbol{D}^{\prime \prime}\right), \operatorname{NPY}\left(\boldsymbol{E}, \boldsymbol{E}^{\prime}\right)$, and more rarely, GFAP $\left(\boldsymbol{C}, \boldsymbol{C}^{\prime}\right)$ by parenchymal $\beta$ gal ${ }^{+}$cells, but not $\beta \mathrm{gal}{ }^{+}$tanycytes, in the hypothalamus of Fgf10 ${ }^{\text {nlacz }}$ mice. C, Side view of a three-dimensionally reconstructed image. $E-E^{\prime \prime}$, A subset of parenchymal $\beta \mathrm{gal}{ }^{+}$cells express the orexigenic neurotransmitter, NPY. $\boldsymbol{E}^{\prime}, \mathbf{E}^{\prime \prime}$, Cut views of a $\beta \mathrm{gal}{ }^{+} / \mathrm{NPY}^{+}$cell. $\boldsymbol{F}-\boldsymbol{G}^{\prime \prime}$, Upregulation of $\mathrm{c}-$ Fos expression and phosphorylated STAT3 in a subset of parenchymal $\beta \mathrm{gal}{ }^{+}$cells, in response to acute fasting alone $\left(\boldsymbol{F}-\boldsymbol{F}^{\prime \prime}\right)$, or after administration of leptin to fasted mice $\left(\boldsymbol{G}-\boldsymbol{G}^{\prime \prime}\right)$. Arc, Arcuate nucleus. Scale bars: $\boldsymbol{A}, \boldsymbol{C}, 50 \mu \mathrm{m} ; \boldsymbol{C}^{\prime}, \boldsymbol{E}-\boldsymbol{G}$, $20 \mu \mathrm{m} ; \boldsymbol{B}-\boldsymbol{B}^{\prime \prime}, \boldsymbol{D}-\boldsymbol{D}^{\prime \prime}, \boldsymbol{F}^{\prime}, \boldsymbol{F}^{\prime \prime}, \boldsymbol{G}^{\prime}, \boldsymbol{G}^{\prime \prime}, 5 \mu \mathrm{m}$.

\section{Results}

Previous studies classified hypothalamic tanycytes into dorsal $(\alpha-1$ and -2$)$ and ventral $(\beta-1$ and -2$)$ subpopulations with different morphological and physiological properties (Rodríguez et al., 2005; Pérez-Martín et al., 2010). To assess the identity of Fgf $10^{+}$tanycytes, we coimmunolabeled brain sections of adult Fgf10 $10^{\text {nlac }}$ report mice with anti- $\beta$ gal and a selection of neural stem (NSC)/progenitor cell markers. Within the $3 \mathrm{~V}$ ependymal layer, $\beta \mathrm{gal}^{+}$cells were most abundant ventrally (Fig. $1 A, B)$. As previously reported (Bennett et al., 2009), nestin was expressed by both $\alpha$ and $\beta$ tanycytes. As with nestin, BLBP and Musashi expression was restricted to the tanycytes and some of their immediate neighbors. By contrast, Sox 2 was additionally expressed by a large number of cells scattered throughout the neighboring parenchyma (Fig. $1 P$ ). At the level of median eminence (ME; bregma -1.58 to -2.3 ), the majority of $\mathrm{Bgal}^{+}$ tanycytes expressed nestin, BLBP, Musashil, and Sox2 (Fig. 1C$R)$. However, nestin ${ }^{+} / \beta \mathrm{gal}^{-}$or $\mathrm{BLBP}^{+} / \beta \mathrm{gal}^{-}$tanycytes were

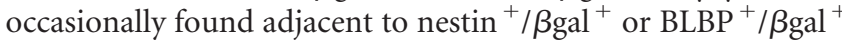
tanycytes (Fig. $1 G, L$ ). At the rostral and caudal limits of the ME, Fgf10 ${ }^{+}$tanycytes were scarce but nestin ${ }^{+}$and $\mathrm{BLBP}^{+}$cells were still abundant (Fig. 1S,T). These observations suggest that tanycytes are heterogeneous.

GFAP was not expressed by ventral ependymal cells, including $\mathrm{Bgal}^{+}\left(\mathrm{Fgfl}^{+}\right)$tanycytes (Fig. $\left.1 \mathrm{~A}, \mathrm{~B}\right)$. To detect GLAST expression, we examined the brains of tamoxifen-treated GLAST ${ }^{\text {creERT2 }}:$ R2 $6^{\text {GFP }}$ double transgenic mice $(n=2)$ (Mori et al., 2006). In contrast to a previous report (Berger and Hediger, 2001), we found no GFP (GLAST) expression in ventral tanycytes, although the domain of GLAST expression extended more ventrally than that of GFAP (Fig. 1, compare $B, B^{\prime} E, E^{\prime}$ ).

Thus, the anatomical location and immunoprofile of $\mathrm{Fgfl}^{+}$tanycytes is consistent with the idea that they belong largely to the $\beta$ subtype and may constitute a population of stem/progenitors cells. Of note, exclusion of GFAP and GLAST from this population implies that the respective Cre reporter lines cannot be used to lineage-trace or target adult $\beta$ tanycytes.

Previously we noted that throughout adult life, the expression of Fgf10 transcripts in the hypothalamus (and indeed LacZ transcripts in Fgf10 ${ }^{\text {nlacZ }}$ hypothalamus) is restricted to tanycytes and absent from parenchymal cells (Hajihosseini et al., 2008). However, as well as a strong $\beta$ gal expression in tanycytes, a significant number of weaker $\beta \mathrm{gal}^{+}$cells are consistently found in the parenchyma of adult Fgf10 ${ }^{\text {nlacZ }}$ hypothalamus (Hajihosseini et al., 2008) (Figs. $1 A, B ; 2 A, C$ ). As a bacterial protein, $\beta$ gal is relatively more stable than endogenous mammalian proteins and Fgf10 ${ }^{\text {nlacZ }}$ mice have previously been used to transiently lineage-trace Fgf $10^{+}$ cells in non-neural tissues in vivo (Kelly et al., 2001; Mailleux et al., 2005). Thus, most likely, parenchymal $\beta_{g a l}{ }^{+}$cells are the descendants of $\mathrm{Fgfl}^{+}$tanycytesexisting as either progenitor cells or differentiated cells. With this premise, we analyzed the expression of $\mathrm{NeuN}$, a maker of mature neurons, and the glial cells markers, $\mathrm{S} 100 \beta$, GFAP, and Olig2, as well as doublecortin, a putative marker of migratory neuroblasts. Fgf $10^{+}$tanycytes themselves did not express these markers, but, with the exception of Olig2, a subset of $\beta \mathrm{gal}^{+}$parenchymal cells did. Furthermore, $\beta \mathrm{gal}^{+}$neurons far outnumbered $\beta \mathrm{gal}^{+}$glial cells (Fig. 2A-D; data not shown). Coimmunolabeling studies also showed that a subset of $\beta \mathrm{gal}^{+}$parenchymal cells in the arcuate nucleus express the orexigenic neuronal maker, neuropeptide Y (NPY; Fig. 2E-E" $)$.

Next, we examined whether parenchymal $\beta \mathrm{gal}^{+}$cells are functionally embedded within the appetite/energy-balance regulating circuits, by assessing whether they response to fasting and/or leptin administration. Fasting alone induced a robust upregulation of the immediate early gene, c-Fos, and administration of leptin to fasted animals (Becskei et al., 2010) resulted in the upregulation of phospho-STAT3 in cells of the arcuate nucleus, a subset of which were clearly $\mathrm{Bgal}^{+}$in Fgf10 ${ }^{\text {nlacZ }}$ brains (Fig. $2 F, G$ ). Control mice (nonstarved or vehicle-treated fasted Fgf10 ${ }^{\text {nlacZ }}$ or wild-type) showed no such effects.

\section{Proliferation of Fgf10 ${ }^{+}$tanycytes declines with age}

To determine whether Fgf10 ${ }^{+}$tanycytes or their putative parenchymal descendants divide, and gain some insight into their cell cycle dynamics, we pulsed Fgf10 ${ }^{\text {nlacz }}$ mice of various ages with 
BrdU, and its less toxic analog, EdU. In anticipation that these cells are likely to cycle slowly, we resorted to cumulative labeling through delivery of BrdU via drinking water or intraperitoneal injections (EdU) for up to $35 \mathrm{~d}$ (Fig. 3A). Animals pulsed for up to $15 \mathrm{~d}$ with BrdU or EdU showed no overt phenotype and so analysis was limited to this time-point. The total number of single $\mathrm{BrdU}^{+}$or EdU ${ }^{+}$cells as well as double-positive cells $\left(\mathrm{BrdU}^{+} /\right.$ $\mathrm{Bgal}^{+}$or $\mathrm{EdU}^{+} / \mathrm{ggal}^{+}$) was determined and their distribution within the ependymal/ME (compartment harboring tanycytes) or parenchyma (harboring mature neural cells) was analyzed (Fig. $3 B-D$ ).

Seventy percent fewer proliferating cells were detected using EdU than BrdU (BrdU: average of $1624 \pm 384$ cells versus EdU: $445 \pm 45$ cells, per brain) (Fig. 3B). This could be due either to differential stability of the two compounds or the exposure of cells via two different labeling routes. Nonetheless, at P60, the relative distribution of $\mathrm{BrdU}^{+}$or $\mathrm{EdU}^{+}$cells in the two compartments was comparable (Fig. 3B). I.e., consistently more labelretaining cells were present in the parenchyma than in the ependymal/ME. This pattern was also seen in P28-P32 pulsed animals, but significantly more $\mathrm{BrdU}^{+}$cells were found in these when compared with P60-pulsed animals (Fig. 3C). Significantly, combined $\mathrm{BrdU} / \beta \mathrm{gal}$ analysis showed that $\mathrm{BrdU}^{+} / \mathrm{Bgal}^{+}$ tanycytes are as numerous in P60-pulsed as P28-P32-pulsed brains (Fig. 3D). No double-positive cells were found in P438 animals, even if pulsed for $21 \mathrm{~d}$ (data not shown).

Most $\mathrm{BrdU}^{+} / \beta \mathrm{gal}^{+}$or $\mathrm{EdU}^{+} / \beta \mathrm{gal}^{+}$cells were found within the ependymal/ME compartment and appeared as pairs of cells undergoing mitosis (Fig. 4). Rare pairs of double-positive cells were also found in the nearby parenchyma (Fig. $4 A, F$ ). Although abundant throughout the hypothalamus (Fig. $4 B$ ), $\mathrm{BrdU}^{+}$or $\mathrm{EdU}^{+}$cells were not found anywhere else in the ependymal lining, suggesting that $\beta \mathrm{gal}^{+}$tanycytes represent the proliferative cells of the ependyma.

Together, these findings show that a considerable number of dividing cells are found in both the ependymal/ME and parenchyma of postnatal/adult mice, but most do not relate to Fgf10expressing cell lineage or may not even be neural in origin. We did, however, find that a subset of Fgf $10^{+}$tanycytes divide at least once every $9-15 \mathrm{~d}$ between the ages of $\mathrm{P} 28-\mathrm{P} 75$, a capacity that is lost by one year of age. Furthermore, Fgf10 ${ }^{-} \alpha$ tanycytes are either nonproliferative, have longer cell cycle times, and/or do not become labeled using our labeling paradigm. Finally, some descendants of Fgf10 ${ }^{+}$tanycytes continue to divide within the parenchyma.

\section{Cumulative contribution of Fgf10 ${ }^{+}$tanycytes to multiple hypothalamic nuclei}

To detail the contribution of Fgf $10^{+}$tanycytes to hypothalamic nuclei, we analyzed the distribution of parenchymal $\beta \mathrm{gal}^{+}$cells in serial coronal sections of $\mathrm{P} 60 \mathrm{Fgf1} 0^{\text {nlacZ }}$ brains. The majority of such cells were found within the arcuate nucleus, with small contributions to the ventromedial and dorsomedial and lateral nuclei (Fig. 5A-I).

Because proliferating Fgf10 ${ }^{+}$tanycytes are scarce and have a long cell cycle time, it is likely that most of the parenchymal $\beta \mathrm{gal}^{+}$cells observed at P60 are products of earlier cell divisions. A cross-age comparison (P4 to P400) showed that indeed parenchymal $\beta \mathrm{gal}^{+}$cells are present as early as $\mathrm{P} 4$ and persist as late as P400 (Fig. $5 J-N$ ). Detailed quantifications (at bregma -1.9) showed that parenchymal $\beta \mathrm{gal}^{+}$cells are most abundant at $\mathrm{P} 4$ and their numbers decline significantly with increasing age (Fig. $5 O)$. By contrast, tanycyte numbers increase between P4 and P60
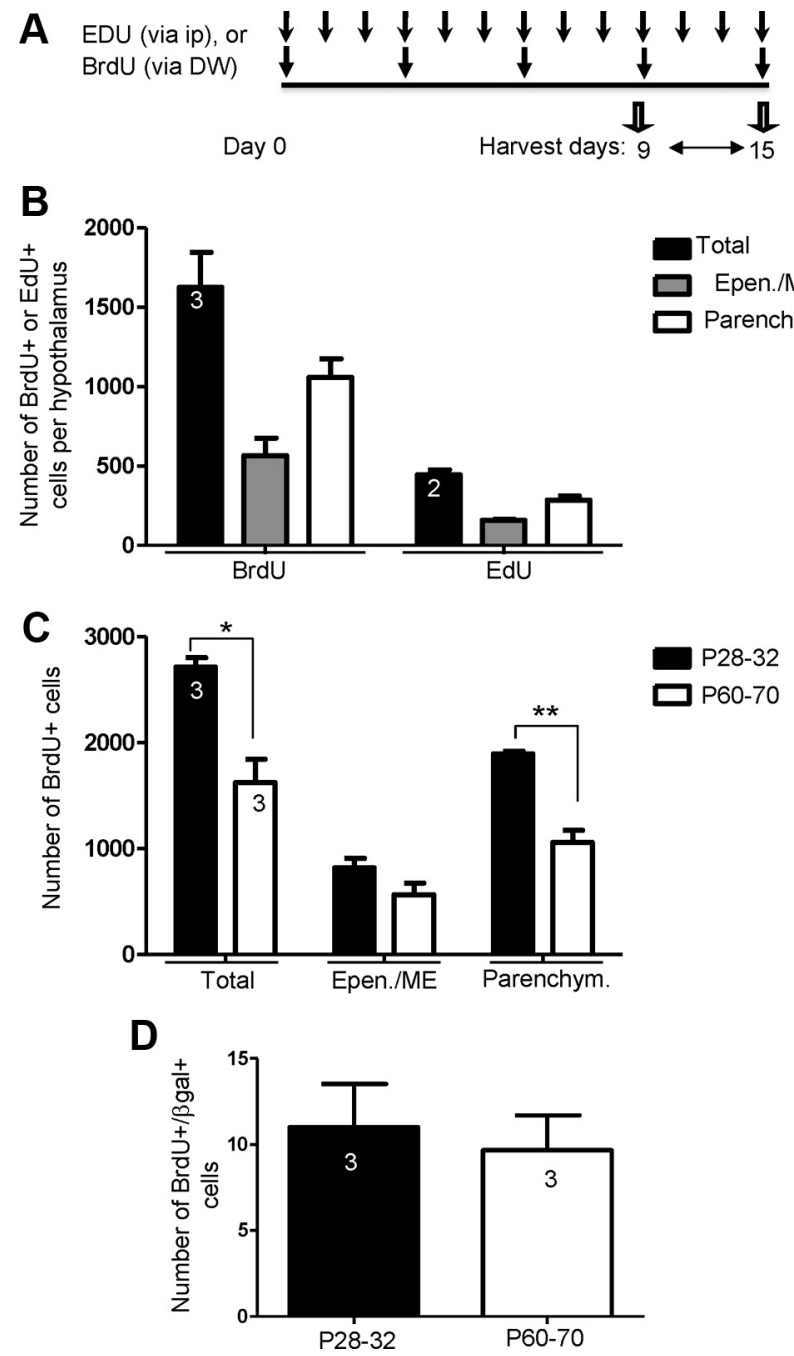

Figure 3. Abundance and distribution of proliferating cells in the postnatal and adult hypothalamus. $A, B$, Cumulative exposure of $\mathrm{P} 60 \mathrm{Fgf1} 10^{\text {nlac }}$ mice to $\mathrm{BrdU}$ or EdU results in labeling of numerous cells in the hypothalamus with more cells being labeled after BrdU than EdU application. Most BrdU- or EdU-incorporating cells are found in the parenchymal compartment. C, A higher level of cell proliferation is observed in animals pulsed at P28 - P32 (early post-weaning stage) compared with adult ( $\mathrm{P} 60-\mathrm{P} 70)$, with the difference relating mostly to parenchymally located cells than ependymal ME cells (where tanycytes reside). $\boldsymbol{D}$, Comparable numbers of $\mathrm{BrdU}^{+} / \beta \mathrm{gal}^{+}$tanycytes are found in P28 -P32 and P60-pulsed animals (similar data were obtained with EdU; data not shown). Number of animals analyzed per condition is shown inside bars. ${ }^{*} p<0.05$; ${ }^{* *} p<0.01$.

before declining at a slower rate than parenchymal cells (Fig. $5 P, Q)$.

Collectively, these observations suggest that postnatal neuro/ gliogenesis is robust perinatally and continues as late as P60. The progressive decline in parenchymal $\beta \mathrm{gal}^{+}$cell numbers may then reflect a reduced contribution from Fgf $10^{+}$tanycytes, temporal decay of $\beta$ gal protein, and/or cell death. As the stability of $\beta$ gal protein is not known, it would be difficult to draw conclusions about the rate of cell turnover among $\beta \mathrm{gal}^{+}$parenchymal cells.

Despite the decline in the number of Fgf $10^{+}$tanycytes (Fig. $5 P)$, the expression of lacZ/ $\beta$ gal in these cells remains intense (Fig. $5 J-N$ ), suggesting that Fgf10 continues to be expressed by these cells late into adulthood (i.e., P150 and P400; Fig. 5 M,N).

\section{Direct lineage tracing of Fgf $10^{+}$tanycytes}

Analysis of Fgf $10^{\text {nlacZ }}$ brains provided indirect evidence and snap shots of neurogenesis within the postnatal/adult hypothalamus. 

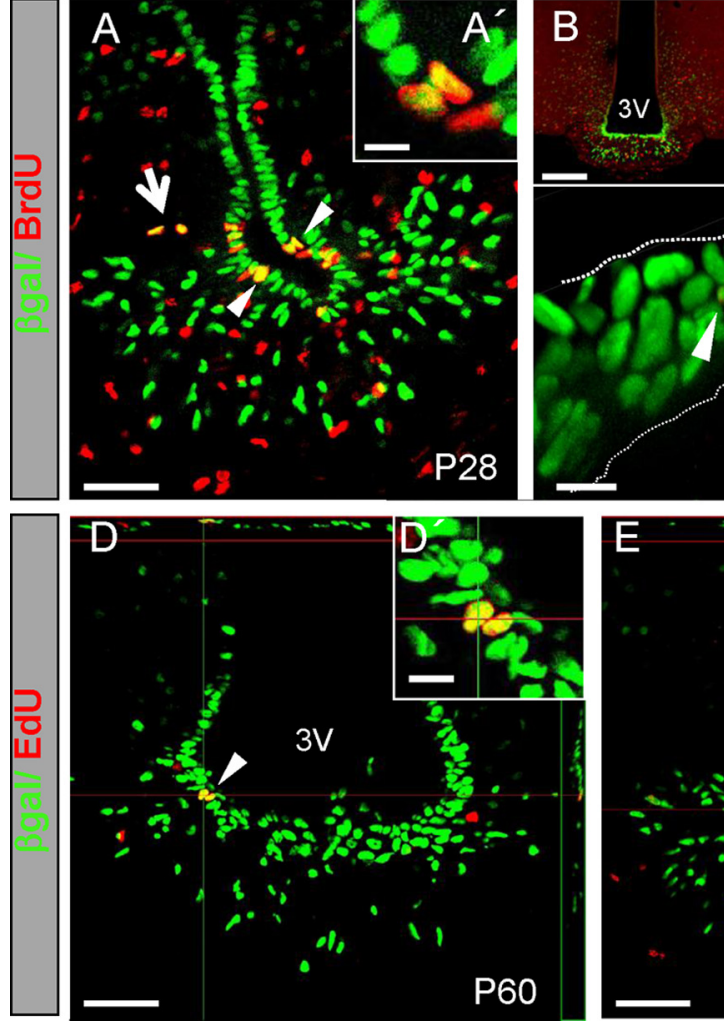

P60
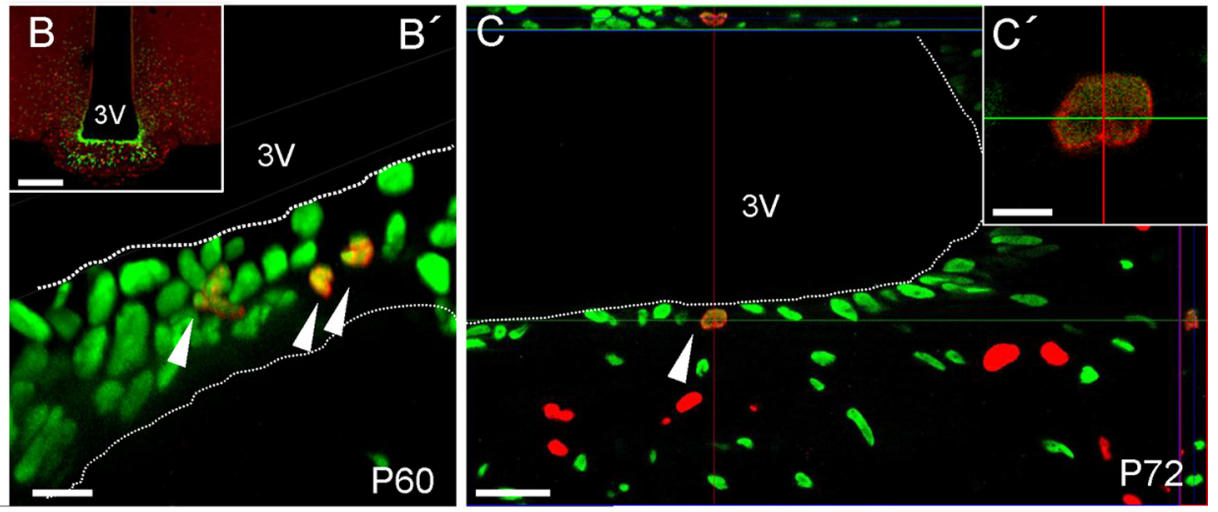

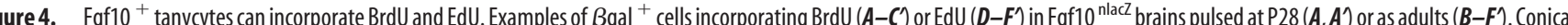
arrowheads heads point to pairs of labeled nuclei located within the ependymal lining, while larger arrows highlight pairs of labeled cells within the nearby parenchyma (in $A, F$ ). Note the parallel $\left(\boldsymbol{C}^{\prime}, \boldsymbol{D}^{\prime}\right)$ versus perpendicular $\left(\boldsymbol{A}^{\prime}, \boldsymbol{E}^{\prime}\right)$ planes of cell division with respect to the plane of the ventricular surface (3V). Scale bars: $\boldsymbol{B}, 100 \mu \mathrm{m} ; \boldsymbol{A}, \boldsymbol{D}, \boldsymbol{E}, \boldsymbol{F}, 50 \mu \mathrm{m} ; \boldsymbol{A}^{\prime}, \boldsymbol{B}^{\prime}, \boldsymbol{C}^{\prime}, \boldsymbol{D}^{\prime}, \boldsymbol{E}^{\prime}, \boldsymbol{F}^{\prime}, 10 \mu \mathrm{m}$.

To directly test the contribution of tanycytes and measure the dynamics of neurogenesis during late postnatal and adult life, we undertook stage-specific lineage-tracing i.e., to induce the constitutive expression of a traceable marker gene within tanycytes at desired time-points, and assess their subsequent contribution to the neighboring parenchymal cell population. This was afforded by findings that Fgf10 mRNA expression is restricted to tanycytes and absent from parenchymal cells of the hypothalamus (Hajihosseini et al., 2008) (Fig. 6L). Attempts to use nestin-creERT2:R26 ${ }^{\text {YFP }}$ or :R26 ${ }^{\text {RFP }}$ double transgenic-mice at these late postnatal stages were unsuccessful, as no YFP/RFP expression could be detected, even by anti-YFP/RFP immunolabeling. To circumvent this problem and specifically target the Fgf $10^{+}$subpopulation, we exploited a recently generated Fgf10 ${ }^{\text {creERT2 }}$ line (Fig. 6A) (El Agha et al., 2012). Thus, young postweaned (P28P32; PW) or adult (P53-P83; Ad) Fgf10 ${ }^{\text {creERT2 }}$ :R26 ${ }^{\text {lac }}$ mice were treated with tamoxifen in line with common protocols for creERT2-mediated recombination in adult tissues, and brains were analyzed thereafter at short $(+10 \mathrm{~d})$ or long $(+22-72 \mathrm{~d})$ survival time points (Fig. $6 B$ ). At each time point, the total number and anatomical distribution of $\mathrm{Xgal}^{+}$cells within the ependyma and parenchyma was determined in serial coronal sections (Fig. $6 C-K^{\prime}$ ). $\mathrm{Xgal}^{+}$cells were never found in the brains of control mice (nontreated double transgenic or tamoxifen-treated single-transgenics).

In brains analyzed immediately after the last tamoxifen dose, recombined cells were predominantly composed of tanycytes themselves with rare $\mathrm{Xgal}^{+}$cells observed in the neighboring parenchyma (data not shown). When analyzed $10 \mathrm{~d}$ later, an average of $101 \pm 47 \mathrm{Xgal}^{+}$cells was found in PW compared with $74 \pm 29$ in Ad brains (Fig. 7A). Of these, 50-60\% were tanycytes themselves, with the remainder residing in the parenchyma (Fig. $7 B, C)$. This comparison shows that the rate of recombination in, and/or amplification of tanycytes themselves, is not significantly different in PW or Ad pulsed brains, analyzed at short time points.

However, differences between the two ages emerged at later survival $(+39-83$ d) time-points. First, the total number of $\mathrm{X}$-gal ${ }^{+}$cells found in PW animals increased to $135 \pm 41$ per brain while that of Ad brains showed a small but nonsignificant drop to $50 \pm 17$ (Fig. 7A). Moreover, while the number of $\mathrm{Xgal}^{+}$ tanycytes dropped (Fig. $7 B$ ), three times more parenchymal $\mathrm{Xgal}^{+}$cells were found in PW than Ad brains (Fig. 7C; $p<$ $0.001)$. Together, these comparisons suggest that there is more lineage amplification when tanycytes are labeled at early postnatal ages, and some of this amplification appears to occur within the parenchyma itself. The latter idea is supported by the discov-

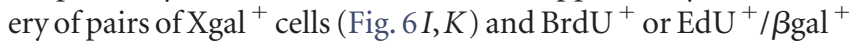
cells in the neighboring parenchyma (Fig. $4 A, F$ ).

To verify these relationships further, we opted for even shorter periods of tamoxifen treatment and survival, focusing on P28 mice. Moreover, we switched to using a Rosa26-tomato allele (i.e., Fgf10 ${ }^{\text {creERT2 }}:$ R2 $6^{\text {Tom }}$ mice), which gives a better cellular resolution of recombined cells. After a $3 \mathrm{~d}$ treatment/survival, 95\% of recombined Tomato ${ }^{+}$cells $(n=101 \pm 37)$ were found within the ependymal layer (Figs. $6 M, 7 D$ ), consistent with the restricted expression of Fgf10 in tanycytes (Fig. $6 \mathrm{~L}$ ). Following 8 or $27 \mathrm{~d}$ of tamoxifen treatment/survival, however, a greater proportion of recombined cells were found in the parenchyma, respectively making up $15 \pm 2 \%(n=50 \pm 4)$ and $28 \pm 1 \%(n=124 \pm 2)$ of the total number of recombined cells per brain (Fig. $\left.6 D^{\prime}\right)$. At these early time-points, the parenchymal Tom ${ }^{+}$cells had short 
processes reaching a maximum of $170 \pm$ $20 \mu \mathrm{m}$ in length (Fig. $6 N^{\prime}$, small arrows and corresponding insets; and data not shown). Moreover, during these analyses we found evidence for focal/clonal amplification of tanycytes within the ependymal layer (Large arrows and corresponding insets in Fig. $\left.6 M^{\prime}, N^{\prime}\right)$. Interestingly, under comparable treatment and survival time points (e.g., $17 \mathrm{~d}$ tamoxifen treatment begun at P28, followed by $10 \mathrm{~d}$ on normal diet), four times more recombined cells were detectable using the R2 $6^{\text {TOM }}$ than R26 ${ }^{\text {LacZ }}$ alleles (446 \pm 26 versus $101 \pm 37$ cells/brain, respectively). Of note, our tamoxifen dosage and regimes were tailored to lineage trace a small subset of tanycytes. Combined, these factors suggest that our quantifications of lineagetraced cells are an underestimate of the magnitude of neurogenesis in the postnatal and adult hypothalamus.

During the course of these studies, we also noted an interesting disparity between the location and number of recombined tanycytes, versus recombined parenchymal cells. For example, at bregma -1.06 , sections were void of recombined $\mathrm{Xgal}^{+}$ tanycytes, yet $\mathrm{Xgal}^{+}$recombined cells were clearly evident in the corresponding parenchyma (Fig. 6J). The disparity was more exaggerated in PW than Ad brains (data not shown). This phenomenon may reflect the displacement of the recombined cells with brain growth or provide evidence for rostra-caudal dispersion of recombined cells from their plane of origin.

\section{A majority of recombined cells become neurons of the arcuate and ventromedial nuclei}

To determine which hypothalamic nuclei and what cell lineage/s the recombined Fgf10 ${ }^{+}$tanycytes contribute to, tamoxifeninduced brains were Xgal-stained and immunoperoxidase labeled with anti-NeuN or anti-GFAP antibodies, as attempts to detect the recombined cells with anti- $\beta$ gal antibodies were unsuccessful. Consistent with the distribution of $\mathrm{Bgal}^{+}$cells in Fgf10 ${ }^{\text {nlacZ }}$ brains (Fig. 5), $\mathrm{Xgal}^{+}$cells were found mostly in the arcuate and ventromedial nuclei. Most $\mathrm{Xgal}^{+}$cells expressed NeuN (78/89 counted across three brains). $\mathrm{No} \mathrm{Xgal}^{+} / \mathrm{GFAP}^{+}$parenchymal cells were found, but this is not surprising, since $\beta \mathrm{gal}^{+} / \mathrm{GFAP}^{+}$ cells were rare in the parenchyma of Fgf10 ${ }^{\text {nlacZ }}$ brains (Fig. $2 C$ ).

To better visualize and validate the identity of parenchymallocated recombined cells, we also analyzed P28-induced Fgf10 ${ }^{\text {creERT2 }}:$ R26 ${ }^{\text {Tom }}$ brains $(n=3)$. Here, too, we found $\mathrm{NeuN}^{+} / \mathrm{Tom}^{+}$cells within the arcuate, ventromedial, dorsomedial, and lateral nuclei. Importantly, following a $29 \mathrm{~d}$ treatment/ survival, $\mathrm{NeuN}^{+} / \mathrm{Tom}^{+}$neurons displayed extensive axonal/ dendritic arborizations easily exceeding $200 \mu \mathrm{m}$ (Fig. $8 \mathrm{H}-\mathrm{K}$, small arrows), supporting the notion that they are mature, inte-

0
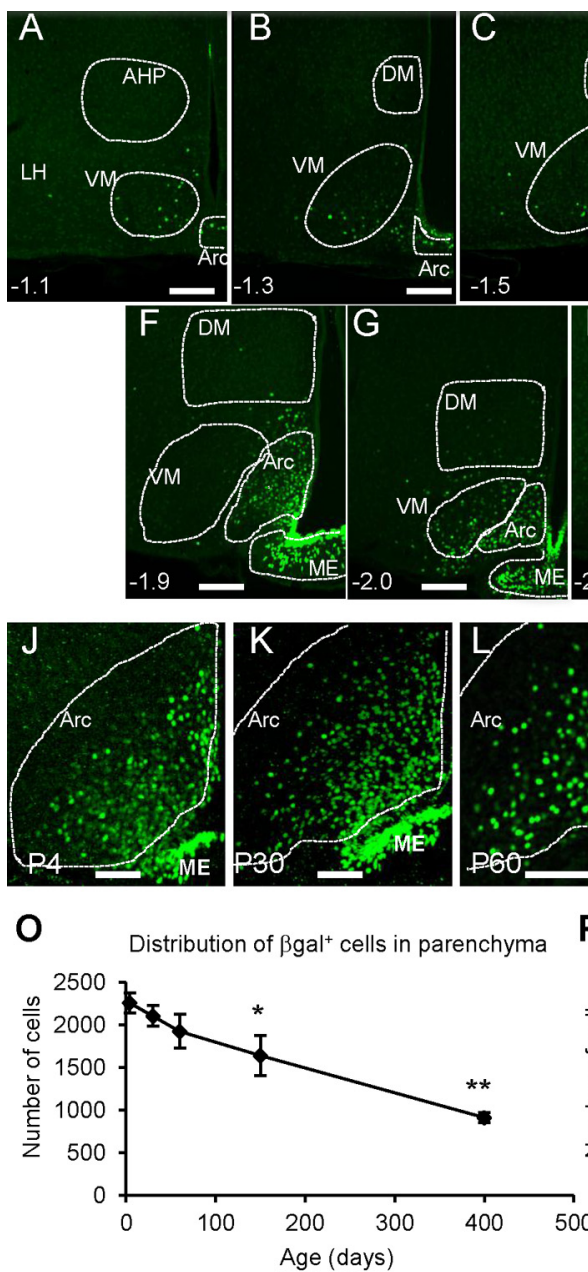

$\mathbf{P}$
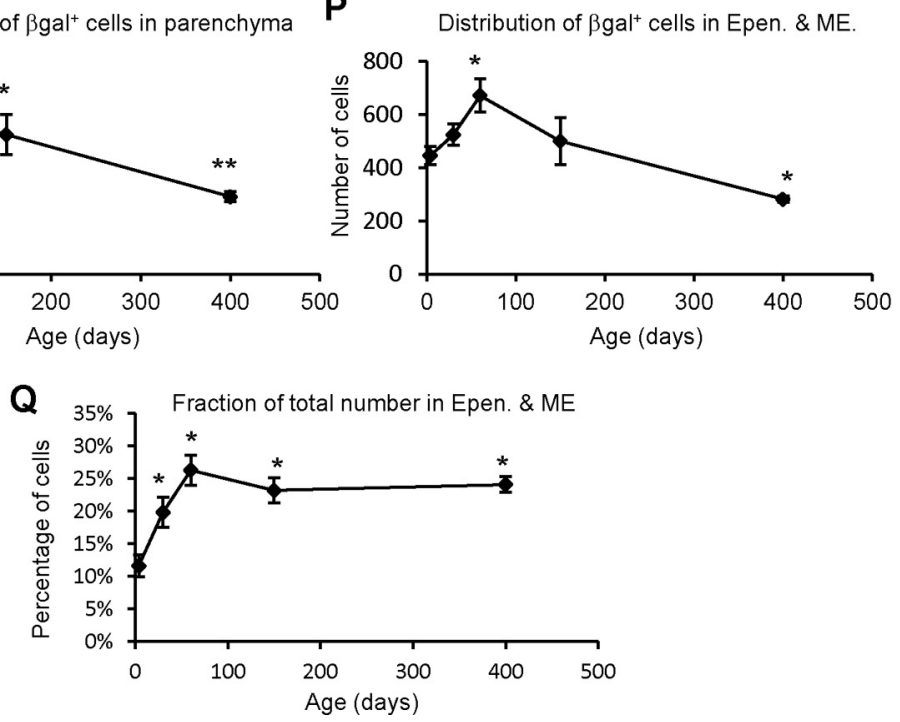

Figure 5. Abundance and contribution of $\mathrm{Fgf} 10^{+}$tanycytes to hypothalamic parenchymal cells. $A-I$, Apparent descendants of Fgf $10^{+}$tanycytes, revealed by $\beta$ gal immunolabeling, occupy the arcuate (Arc), ventromedial (VM), and to a lesser degree the dorsomedial (DM) and lateral (LH) hypothalamic nuclei at P60. J-N, Cross age comparison shows a conserved presence of such descendants in the arcuate nucleus. Note the reduction in the intensity of $\beta$ gal label in parenchymal, but not ependymal point on each graph represent $\mathrm{P} 4, \mathrm{P} 30, \mathrm{P} 60, \mathrm{P} 150$, and $\mathrm{P} 400$, respectively. $n=3$ for each age group. ${ }^{*} p<0.05$; ${ }^{* *} p<0.01$. Scale bars: $A-I, 75 \mu \mathrm{m} ; J-N, 50 \mu \mathrm{m}$.

grated neurons. This was further supported by finding that phopho-STAT3 is upregulated in some arcuate $\mathrm{Tom}^{+}$cells, in response to acute food deprivation and Leptin administration in tamoxifen-treated Fgf10 ${ }^{\text {creERT2 }}:$ R2 $6^{\text {Tom }}$ mice (Fig. $\left.8 L-O\right)$.

\section{Discussion}

Previous studies, including our own, speculated that the ependymal lining of the third ventricle harbors neurogenic cells. Elegant studies showed that these can respond to exogenous growth factors to generate parenchymal neurons (Pencea et al., 2001; Kokoeva et al., 2005; Xu et al., 2005; Pérez-Martín et al., 2010). However, the precise identity of the neurogenic cells and the 
A
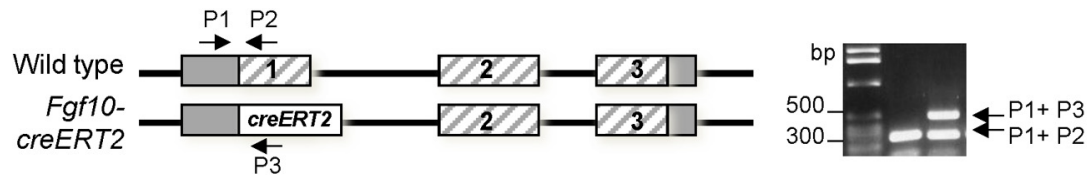

B
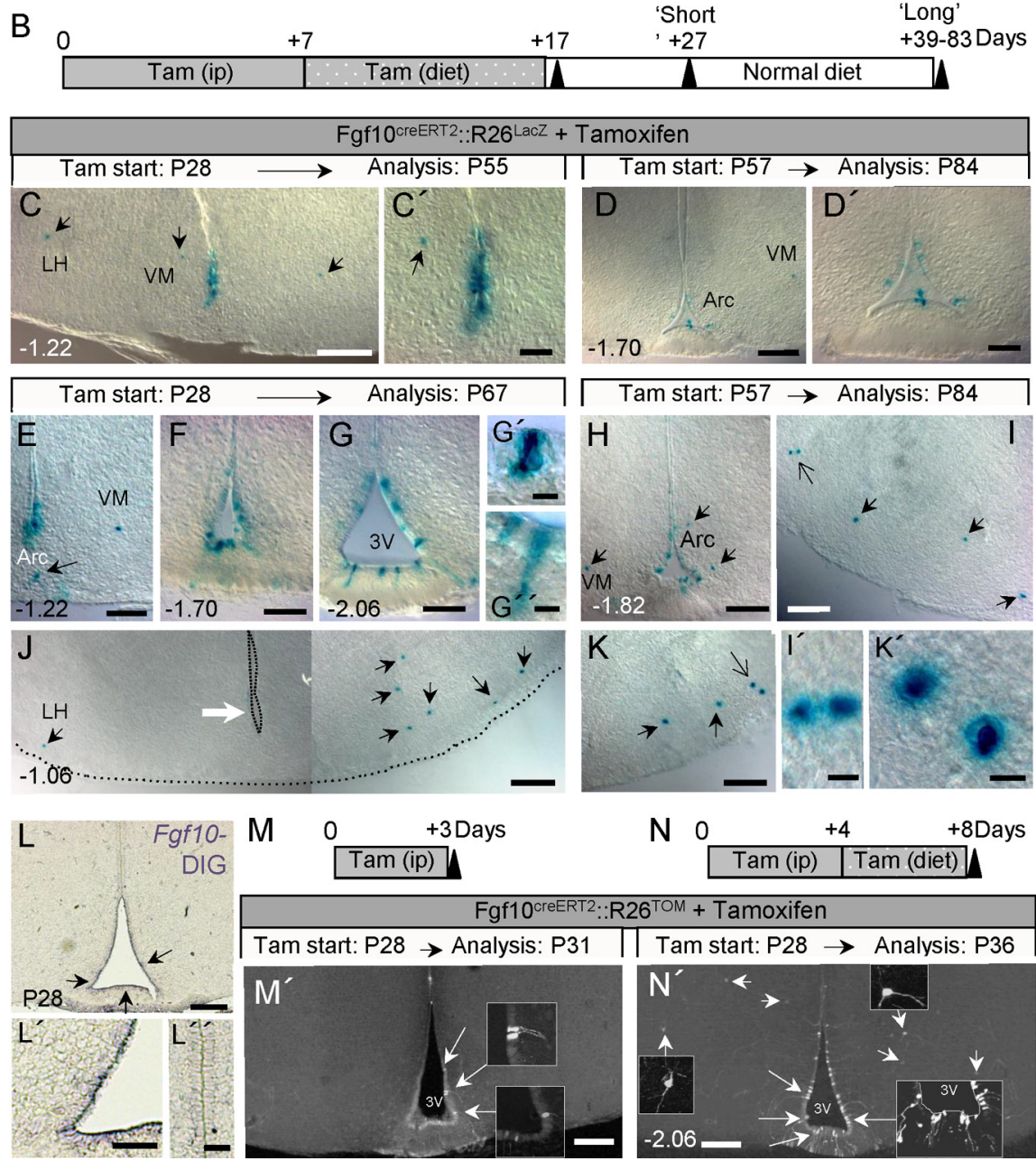

$\mathrm{N} 0$
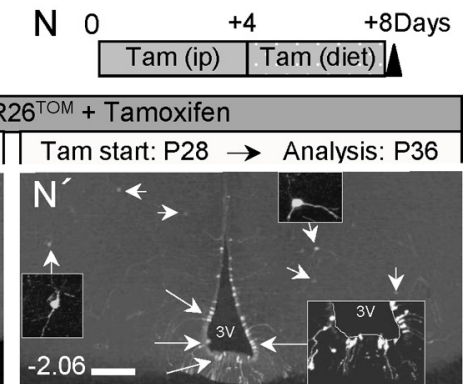

Figure 6. Direct lineage tracing of Fgf10 ${ }^{+}$tanycytes using Fgf10 creERT2 and R2 ${ }^{\text {LacZ }}$ reporter mice. $A$, Schematic of Fgf10 gene locus showing its coding exons (hatched bars), the knock-in creERT2 transgene, as well as the position of genotyping primers (P1-P3) and the resulting PCR products, used to distinguish between the two alleles. $\boldsymbol{B}$, Strategy for tamoxifen application and time course analysis of tamoxifen-treated animals. $\mathbf{C}-\boldsymbol{K}^{\prime}$, Images of recombined $\left(\mathrm{Xgal}^{+}\right)$cells in the hypothalamus of tamoxifentreated Fgf10 ${ }^{\text {creERT2. }}$ :R26 ${ }^{\text {LacZ }}$ mice analyzed at short (C-D) or long $\left(\boldsymbol{E}-\boldsymbol{K}^{\prime}\right)$ time-points after the last tamoxifen dose. Large white arrow in $J$ points to the absence of recombined tanycytes at bregma -1.06 , contrasted with the presence of Xgal ${ }^{+}$cells in the neighboring parenchyma (black arrows). Large open arrows in $\boldsymbol{I}$ and $\boldsymbol{K}$ point to pairs of Xgal ${ }^{+}$parenchymal cells, magnified in $\boldsymbol{I}^{\prime}$ and $\boldsymbol{K}^{\prime}$, respectively. $\boldsymbol{L}-\boldsymbol{L}^{\prime \prime}$, In situ hybridization using DIG-labeled probes shows expression of $F g f 10$ by ventral ependymal cells ( $\boldsymbol{L}$, $\boldsymbol{L}^{\prime}$, arrows) but neither by dorsal ependymal ( $\left.\boldsymbol{L}^{\prime \prime}\right)$ nor by neighboring parenchymal cells at P28. $\boldsymbol{M}-\boldsymbol{N}^{\prime}$, Very short term recombination analysis after $3\left(\boldsymbol{M}, \boldsymbol{M}^{\prime}\right)$ or $8\left(\boldsymbol{N}, \boldsymbol{N}^{\prime}\right)$ d of tamoxifen-treatment of Fgf10 ${ }^{\text {creERT2 }}$ :R26 ${ }^{\text {TOM }}$ mice. Recombination is restricted to tanycytes after a $3 \mathrm{~d}$ treatment (large arrows and insets in $\boldsymbol{M}^{\prime}$ ) while both recombined tanycytes (large arrows) and parenchymal cells (small arrows) are evident following an $8 \mathrm{~d}$ pulse ( $\boldsymbol{N}^{\prime}$ ). Scale bars: $\boldsymbol{C}, \boldsymbol{D}, \boldsymbol{H}, \boldsymbol{L}, \boldsymbol{M}^{\prime}, \boldsymbol{N}^{\prime}, 100 \mu \mathrm{m} ; \boldsymbol{C}^{\prime}, \boldsymbol{D}^{\prime}, \boldsymbol{E}-\mathbf{G}, \boldsymbol{I}-\boldsymbol{K}, \boldsymbol{L}^{\prime}, 50 \mu \mathrm{m} ; \boldsymbol{L}^{\prime \prime}$, $25 \mu \mathrm{m} ; \boldsymbol{I}^{\prime}, \boldsymbol{K}^{\prime}, 5 \mu \mathrm{m}$.

dynamics of in vivo neurogenesis in unchallenged brain have remained elusive, particularly during late postnatal and adult life. Several studies have suggested that the neural stem/progenitor cells reside within the hypothalamic parenchyma (Pierce and Xu, 2010; Li et al., 2012; McNay et al., 2012), while lineage-tracing studies, restricted to P4 in mice, suggest that tanycytes are the neurogenic cells, generating mostly ME neurons at this early stage (Lee et al., 2012).

In this study, we sought to determine the potential of tanycytes, during late postnatal and adult life. Exploiting the restricted expression of Fgf10 to these cells (Hajihosseini et al.,
2008), we used two Fgf10 transgenic lines as convenient tools to investigate their potential and gain some insights into the dynamics of neurogenesis. Our findings further document the occurrence of neurogenesis at these late stages, but also provide the most direct evidence yet that $\beta$ $\left(\mathrm{Fgfl} 10^{+}\right)$-tanycytes normally generate parenchymal neurons, and to a lesser extent glial cells, in vivo.

\section{Neurogenic capacity and heterogeneity of tanycytes}

Adult neural stem cells of the SGZ and SVZ resemble radial glial cells and express nestin, GFAP, vimentin (in SVZ), and BLBP (in SGZ) (Ming and Song, 2011; Bonaguidi et al., 2012). Hypothalamic tanycytes have clear radial glial cell-like morphology and have been shown to express nestin, vimentin, and Sox2 (Millhouse, 1971; Rodríguez et al., 2005; Bennett et al., 2009) (Fig. 1P), thus resembling neural stem/progenitor cells. Intriguingly, our detailed immunolabeling studies revealed a ventral $\mathrm{Fgfl}^{+} / \mathrm{BLBP}^{+} / \mathrm{GFAP}^{-} / \mathrm{GLAST}^{-}$ $\beta$ subtype, versus a more dorsal $\mathrm{Fgfl}^{-} /$ $\mathrm{BLBP}^{-} / \mathrm{GFAP}^{+} / \mathrm{GLAST}^{+} / \mathrm{S} 100 \beta^{+} \alpha$ subtype. The combination of these markers may signify the different potentials of the two subtypes. In our BrdU/EdU labeling paradigm, Fgf10 ${ }^{+}$tanycytes cycled at least once every 9-15 d, but none of the more dorsally located putative $\alpha$ tanycytes were labeled. Also, the Fgf10 ${ }^{+} \beta$-tanycytes contributed mostly to ventrally located parenchymal neurons. Hence, $\alpha$ tanycytes may cycle at much slower rates, and if neurogenic, may generate a different cohort of neurons, or merely glial cells. Direct lineage tracing of the $\alpha$ population should help resolve this question.

Not all Fgf10 ${ }^{+}$tanycytes express nestin or BLBP and indeed at the rostral and caudal limits of the median eminence, $\mathrm{Fgfl}^{+} / \mathrm{nestin}^{+}$or $\mathrm{Fgfl} 0^{+} /$ $\mathrm{BLBP}^{+}$double-positive tanycytes are outnumbered by cells expressing nestin or BLBP alone (Fig. 1S,T). This implies that there is also some degree of heterogeneity within in the $\beta$ subtype itself, possibly reflective of a lineage hierarchy.

Lee et al. (2012) reported that when nestin-cre lineage-traced at $\mathrm{P} 4, \beta$ tanycytes contribute mostly to the neurons of the median eminence and very little to parenchymal neurons, which contrasts with the dramatic contribution of Fgfl $10^{+}$tanycytes to parenchymal neurons at P28 and thereafter, as reported here. Moreover, we found no evidence that Fgf10 ${ }^{+}$tanycytes generate ME neurons. For example, in P28 tamoxifen-treated Fgf10 ${ }^{\text {creERT2 }}: \mathrm{R}^{2} 6^{\text {Tomato }}$ brains, most of the ME-located recombined cells had very clear radial tanycyte-like morphology (Figs. $6 M^{\prime}, N^{\prime}, 8 H$; and data not shown). 
One interpretation of these differences is that ME and parenchymal neurons emerge from different populations of $\beta$ tanycytes, or, that $\beta$ tanycytes switch to generating more parenchymal neurons with increasing postnatal age. Nestin-cre lineage tracing at later postnatal ages compared with Fgf10 $0^{\text {creERT2 }}$ lineage tracing at $\mathrm{P} 4$ may shed some light on these differences, although, in our experience, nestincre mice are ineffective for lineage tracing of tanycytes in P28 or older mice.

\section{Amplification of tanycytes and their parenchymally located daughters}

As neurogenic cells, Fgf10 ${ }^{+}$tanycytes may divide symmetrically to amplify themselves or asymmetrically to additionally generate a committed daughter cell with a neuronal and/or glial fate. Our BrdU/EdU pulse studies of Fgf $10^{\text {nlacZ }}$ brains were insufficient to calculate exact cell proliferation dynamics and distinguish between these two alternatives. Nonetheless, we found examples of $\mathrm{BrdU}^{+}$ $\left(\right.$ or EdU $\left.{ }^{+}\right) / \beta g a l{ }^{+}$tanycytic nuclei dividing either in parallel or perpendicular to the third ventricle ependymal surface (Fig. 4). Further investigations involving, for example, the inheritance of Notch signaling pathway and PAR complex proteins by these cells, should resolve whether these orientations correspond to a particular mode of division and/or whether one mode predominates over another with progressive age, as is the case during early phases of cortical neurogenesis (Noctor et al., 2008) (for review, see Lancaster and Knoblich, 2012).

A contentious issue is whether hypothalamic neurogenesis is restricted to tanycytes or whether it continues within the parenchymal compartment. Our lineage-tracing studies, using two different traceable markers (lacZ and Tomato), showed that with time, there is a significant increase in the number of parenchymally located recombined cells-not matched in magnitude by the number of recombined tanycytes. This was particularly evident in P28-induced animals. This increase suggests that upon departure from the ependymal region, some daughters of Fgf10 ${ }^{+}$tanycytes remain undifferentiated and continue to divide within the neighboring parenchyma. In support of this notion, we found pairs of $\mathrm{BrdU}^{+}$or EdU ${ }^{+} / \beta \mathrm{gal}^{+}$cells within the parenchyma of Fgf $10^{\text {nLacZ }}$ brains and some of the parenchymally located recombined cells in Fgf10 $0^{\text {creERT2 }}:$ R26 ${ }^{\text {lacZ }}$ brains appeared to be the result of recent mitoses. Pairs of $\mathrm{BrdU}^{+}$parenchymal cells have also been observed by Kokoeva et al. (2007), albeit in more dorsal parenchyma than reported here.

Thus, in addition to tanycytes, hypothalamic parenchyma may also harbor dividing progenitor cells to compensate for neuronal loss during normal and diet-induced cell turnover (McNay et al., 2012) or following experimental ablation (Pierce and $\mathrm{Xu}$, 2010), during early postnatal but not adult life.

Future studies should determine whether these postnatal/ adult parenchymal progenitor cells are ultimately derived from tanycytes in general and/or from an Fgf10-expressing cell lineage, in particular. Fgf10-expressing $(\beta)$ tanycytes are not a
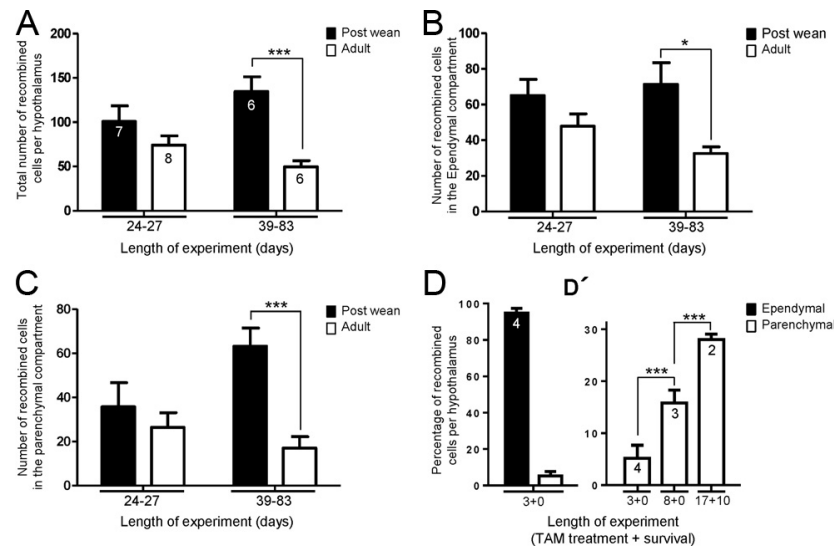

Figure 7. Quantification and spatial distribution of Fgf $10^{\text {creERT2 }}$ lineage-traced cells in early postnatal and young adult mice. $\boldsymbol{A}$, In general, more $\mathrm{Xgal}^{+}$recombined cells are detected in animals treated with tamoxifen at P28 -P32 (a week after weaning) versus adulthood (P53-P83), whether examined after short (24-27 d) or long (39-83d) survival time points. $\boldsymbol{B}$, The number of recombined tanycytes is not significantly different in postweaned and adult animals analyzed at short time points. A significant difference emerges with longer time-point analysis. C, There is a dramatic amplification of parenchymally located recombined cells in postweaned (P28-P32) treated animals when compared with adults. $\boldsymbol{D}, \boldsymbol{D}^{\prime}$, Quantifications under shorter tamoxifen-treatment/survival time periods using R26 ${ }^{\text {Tom }}$ allele. $\boldsymbol{D}$, After a 3 d treatment of P28 Fgf10 ${ }^{\text {creERT2 }}$ :R2 $6{ }^{\text {tomato }}$ mice, the vast majority of recombined $\left(\mathrm{Tom}^{+}\right)$cells are composed of tanycytes, residing in the ependymal layer. $\boldsymbol{D}^{\prime}$, Longer treatment/survival of P28-treated animals results in a significant amplification of parenchymally located recombined cells. Number within bars represent the number of animals analyzed per treatment. ${ }^{*} p<0.05 ;{ }^{* * *} p<0.001$.
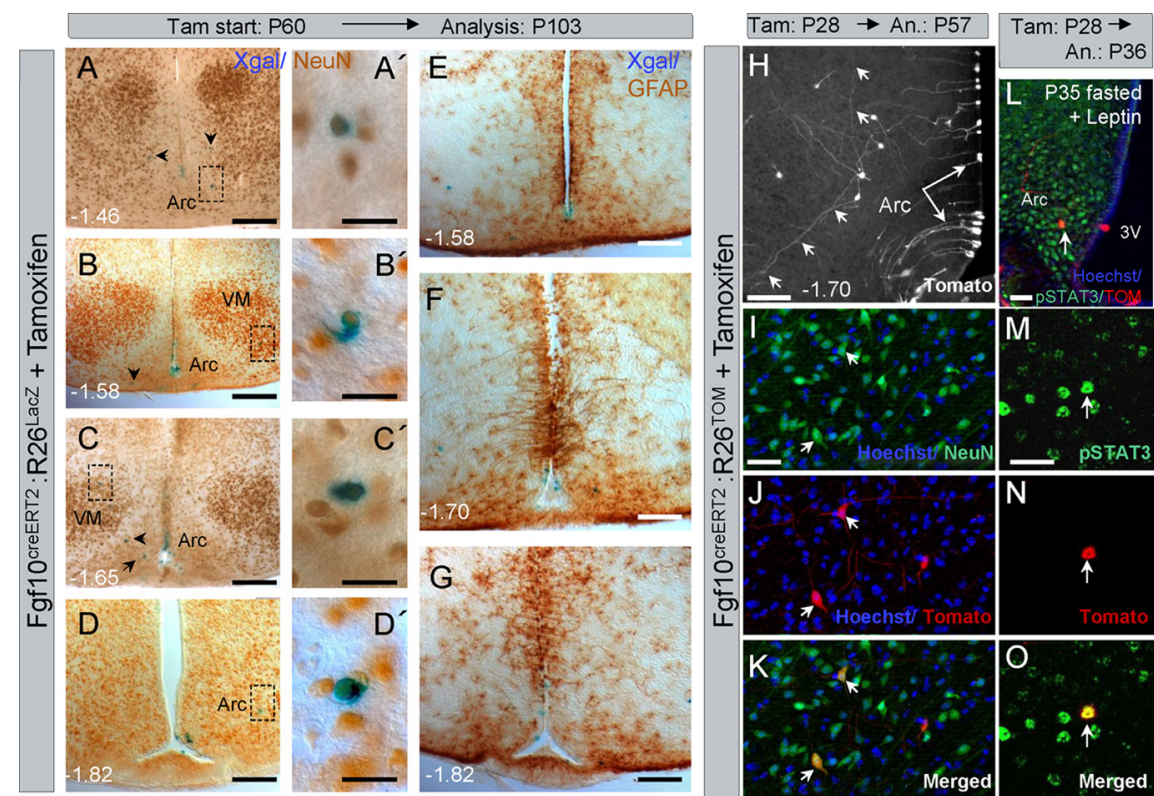

Figure 8. Fgf10 creERT2 lineage-traced cells generate neurons in multiple hypothalamic nuclei and can respond to acute fasting. $\boldsymbol{A}-\boldsymbol{G}$, Immunoperoxidase labeling for NeuN $\left(\boldsymbol{A}-\boldsymbol{D}^{\prime}\right)$ or GFAP $(\boldsymbol{E}-\boldsymbol{G})$ shows that adult lineage traced $\left(\mathrm{Xgal}^{+}\right)$cells can differentiate into neurons of the arcuate and ventromedial nuclei. Lineage-traced cells do not express GFAP $(\boldsymbol{E}-\boldsymbol{G}) \cdot \boldsymbol{H}-\boldsymbol{K}$, Better visualization of P28 lineage-traced cells through the use of Fgf10 ${ }^{\text {creERT2 }}$ :R26 ${ }^{\text {tomato }}$ line confirms the radial morphology of the recombined tanycytes (long arrows) as well as the elaborate axonal/dendritic arborization ( $H$, short arrows) of their parenchymally located neural descendants, whose neuronal identity is confirmed by NeuN labeling (short arrows in $\boldsymbol{I}-\boldsymbol{K}$ ). $\mathbf{L}-\mathbf{0}$, An example of a P28 lineage-traced $\left(\mathrm{Tom}^{+}\right)$arcuate neuron that has responded to fasting and in vivo leptin treatment by expressing phospho-STAT3. Scale bars: $\boldsymbol{A}-\boldsymbol{D}, \boldsymbol{E}-\boldsymbol{H}, 75 \mu \mathrm{m} ; \boldsymbol{L}, 30 \mu \mathrm{m} ; \boldsymbol{A}^{\prime}, \boldsymbol{B}^{\prime}, \boldsymbol{C}^{\prime}, \boldsymbol{D}^{\prime}, \boldsymbol{I}, \boldsymbol{M}, 15 \mu \mathrm{m}$. major source of putative Sox2-expressing parenchymal progenitor cells (Li et al., 2012), however, since very few parenchymally located $\beta$ gal + cells in Fgf10 ${ }^{\text {nLacZ }}$ brains express Sox2 (Fig. 1P; and data not shown). 


\section{Significance of postnatal neurogenesis and contribution of Fgf10 ${ }^{+}$tanycytes}

The majority of hypothalamic neurons are generated during embryogenesis (Shimada and Nakamura, 1973). However, during postnatal and adult life, the hypothalamus regulates a diverse set of adaptable functions, ranging from thermoregulation and circadian rhythm to appetite/energy balance. Thus, addition of new median eminence neurons at day P4 (Lee et al., 2012), and a significant number of parenchymal neurons at later stages, documented here, may be crucial to its short- or long-term functional plasticity and adaptability. Indeed, postnatal hypothalamus can functionally accommodate new neurons, as demonstrated by transplantation of embryonic progenitor cells into the postnatal parenchyma (Czupryn et al., 2011).

The present study shows that Fgf10 ${ }^{+}$tanycytes contribute primarily to neurons of the arcuate and to a lesser degree the ventromedial, dorsomedial, and the lateral hypothalamic nuclei. Collectively, the main but not the sole function of these nuclei is to regulate appetite, energy balance and satiety. Indeed, some of the $\mathrm{Bgal}^{+}$cells in arcuate nucleus express NPY, a neurotransmitter associated with positive regulation of appetite, and are well integrated into appetite/energy balance regulating circuits, as evidenced by their response to fasting/leptin (Figs. $2 F, G, 8 L-O$ ) and elaborate dendritic arborization (Fig. $8 H$ ). Thus, it is tempting to speculate that the neurons that are derived from an Fgf10expressing lineage have a role in malleability of neural circuits that regulate appetite, particularly during early postnatal life when neurogenesis is more robust. Nonetheless, if/when stimulated by the appropriate signals, Fgf10 ${ }^{+}$tanycytes may continue to fulfill this role during adulthood, as exemplified by infusion of growth factors into the third ventricle (Kokoeva et al., 2005; Xu et al., 2005; Pérez-Martín et al., 2010).

\section{Mode of Fgf10 function}

The role of Fgf10 itself in this system remains to be determined. Fgf Receptor 2-IIIb (FgfR2-IIIb) and FgfR1-IIIb splice isoforms are the main, if not the sole, mediators of the effects of Fgf10 during paracrine cell interactions that govern organogenesis in utero (De Moerlooze et al., 2000; Zhang et al., 2006; Hajihosseini et al., 2009). However, their intriguing absence from the whole hypothalamus (Hajihosseini et al., 2008) argues against this mode of action. Some FGFs, including FGF3, a close relative of FGF10, are known to function intracellulary (Antoine et al., 2005). Thus, Fgf10 may also act through a novel cell-autonomous (intracellular) mechanism to regulate the survival, proliferation, and differentiation of tanycytes, or indeed some important aspects of their physiological functions (Rodríguez et al., 2005). Conditional loss and gain-of-Fgf10 function studies combined with lineage-tracing should help elucidate some of its functions.

\section{References}

Antoine M, Reimers K, Wirz W, Gressner AM, Müller R, Kiefer P (2005) Fibroblast growth factor 3 , a protein with a dual subcellular fate, is interacting with human ribosomal protein S2. Biochem Biophys Res Commun 338:1248-1255. CrossRef Medline

Becskei C, Lutz TA, Riediger T (2010) Reduced fasting-induced activation of hypothalamic arcuate neurons is associated with hyperleptinemia and increased leptin sensitivity in obese mice. Am J Physiol Regul Integr Comp Physiol 299:R632-R641. CrossRef Medline

Bennett L, Yang M, Enikolopov G, Iacovitti L (2009) Circumventricular organs: a novel site of neural stem cells in the adult brain. Mol Cell Neurosci 41:337-347. CrossRef Medline

Berger UV, Hediger MA (2001) Differential distribution of the glutamate transporters GLT-1 and GLAST in tanycytes of the third ventricle. J Comp Neurol 433:101-114. CrossRef Medline
Blouet C, Schwartz GJ (2010) Hypothalamic nutrient sensing in the control of energy homeostasis. Behav Brain Res 209:1-12. CrossRef Medline

Bonaguidi MA, Song J, Ming GL, Song H (2012) A unifying hypothesis on mammalian neural stem cell properties in the adult hippocampus. Curr Opin Neurobiol 22:754-761. CrossRef Medline

Czupryn A, Zhou YD, Chen X, McNay D, Anderson MP, Flier JS, Macklis JD (2011) Transplanted hypothalamic neurons restore leptin signaling and ameliorate obesity in $\mathrm{db} / \mathrm{db}$ mice. Science 334:1133-1137. CrossRef Medline

De Moerlooze L, Spencer-Dene B, Revest JM, Hajihosseini M, Rosewell I, Dickson C (2000) An important role for the IIIb isoform of fibroblast growth factor receptor 2 (FGFR2) in mesenchymal-epithelial signalling during mouse organogenesis. Development 127:483-492. Medline

El Agha E, Al Alam D, Carraro G, MacKenzie B, Goth K, De Langhe SP, Voswinckel R, Hajihosseini MK, Rehan VK, Bellusci S (2012) Characterization of a novel fibroblast growth factor 10 (Fgf10) knock-in mouse line to target mesenchymal progenitors during embryonic development. PLoS One 7:e38452. CrossRef Medline

Franklin KB, Paxinos G (2007) The mouse brain in stereotaxic coordinates, Ed 3. San Diego: Elsevier.

Furusho M, Kaga Y, Ishii A, Hébert JM, Bansal R (2011) Fibroblast growth factor signaling is required for the generation of oligodendrocyte progenitors from the embryonic forebrain. J Neurosci 31:5055-5066. CrossRef Medline

Gould E (2007) How widespread is adult neurogenesis in mammals? Nat Rev Neurosci 8:481-488. CrossRef Medline

Hajihosseini MK (2008) Fibroblast growth factor signaling in cranial suture development and pathogenesis. Front Oral Biol 12:160-177. Medline

Hajihosseini MK, De Langhe S, Lana-Elola E, Morrison H, Sparshott N, Kelly R, Sharpe J, Rice D, Bellusci S (2008) Localization and fate of Fgf10expressing cells in the adult mouse brain implicate Fgf10 in control of neurogenesis. Mol Cell Neurosci 37:857-868. CrossRef Medline

Hajihosseini MK, Duarte R, Pegrum J, Donjacour A, Lana-Elola E, Rice DP, Sharpe J, Dickson C (2009) Evidence that Fgf10 contributes to the skeletal and visceral defects of an Apert syndrome mouse model. Dev Dyn 238:376-385. CrossRef Medline

Hasegawa H, Ashigaki S, Takamatsu M, Suzuki-Migishima R, Ohbayashi N, Itoh N, Takada S, Tanabe Y (2004) Laminar patterning in the developing neocortex by temporally coordinated fibroblast growth factor signaling. J Neurosci 24:8711-8719. CrossRef Medline

Itoh N, Ornitz DM (2011) Fibroblast growth factors: from molecular evolution to roles in development, metabolism and disease. J Biochem 149: 121-130. CrossRef Medline

Kelly RG, Brown NA, Buckingham ME (2001) The arterial pole of the mouse heart forms from Fgf10-expressing cells in pharyngeal mesoderm. Dev Cell 1:435-440. CrossRef Medline

Kokoeva MV, Yin H, Flier JS (2005) Neurogenesis in the hypothalamus of adult mice: potential role in energy balance. Science 310:679-683. CrossRef Medline

Kokoeva MV, Yin H, Flier JS (2007) Evidence for constitutive neural cell proliferation in the adult murine hypothalamus. J Comp Neurol 505: 209-220. CrossRef Medline

Lancaster MA, Knoblich JA (2012) Spindle orientation in mammalian cerebral cortical development. Curr Opin Neurobiol 22:737-746. CrossRef Medline

Lee DA, Bedont JL, Pak T, Wang H, Song J, Miranda-Angulo A, Takiar V, Charubhumi V, Balordi F, Takebayashi H, Aja S, Ford E, Fishell G, Blackshaw S (2012) Tanycytes of the hypothalamic median eminence form a diet-responsive neurogenic niche. Nat Neurosci 15:700-702. CrossRef Medline

Li J, Tang Y, Cai D (2012) IKKbeta/NF-kappaB disrupts adult hypothalamic neural stem cells to mediate a neurodegenerative mechanism of dietary obesity and pre-diabetes. Nat Cell Biol 14:999-1012. CrossRef Medline

Luquet S, Perez FA, Hnasko TS, Palmiter RD (2005) NPY/AgRP neurons are essential for feeding in adult mice but can be ablated in neonates. Science 310:683-685. CrossRef Medline

Mailleux AA, Kelly R, Veltmaat JM, De Langhe SP, Zaffran S, Thiery JP, Bellusci S (2005) Fgf10 expression identifies parabronchial smooth muscle cell progenitors and is required for their entry into the smooth muscle cell lineage. Development 132:2157-2166. CrossRef Medline

Markakis EA, Palmer TD, Randolph-Moore L, Rakic P, Gage FH (2004) 
Novel neuronal phenotypes from neural progenitor cells. J Neurosci 24: 2886-2897. CrossRef Medline

McNay DE, Briançon N, Kokoeva MV, Maratos-Flier E, Flier JS (2012) Remodeling of the arcuate nucleus energy-balance circuit is inhibited in obese mice. J Clin Invest 122:142-152. CrossRef Medline

Migaud M, Batailler M, Segura S, Duittoz A, Franceschini I, Pillon D (2010) Emerging new sites for adult neurogenesis in the mammalian brain: a comparative study between the hypothalamus and the classical neurogenic zones. Eur J Neurosci 32:2042-2052. CrossRef Medline

Millhouse OE (1971) A Golgi study of third ventricle tanycytes in the adult rodent brain. Z Zellforsch Mikrosk Anat 121:1-13. CrossRef Medline

Min H, Danilenko DM, Scully SA, Bolon B, Ring BD, Tarpley JE, DeRose M, Simonet WS (1998) Fgf-10 is required for both limb and lung development and exhibits striking functional similarity to Drosophila branchless. Genes Dev 12:3156-3161. CrossRef Medline

Ming GL, Song H (2011) Adult neurogenesis in the mammalian brain: significant answers and significant questions. Neuron 70:687-702. CrossRef Medline

Mori T, Tanaka K, Buffo A, Wurst W, Kühn R, Götz M (2006) Inducible gene deletion in astroglia and radial glia-a valuable tool for functional and lineage analysis. Glia 54:21-34. CrossRef Medline

Noctor SC, Martinez-Cerdeño V, Kriegstein AR (2008) Distinct behaviors of neural stem and progenitor cells underlie cortical neurogenesis. J Comp Neurol 508:28-44. CrossRef Medline

Nyeng P, Norgaard GA, Kobberup S, Jensen J (2007) FGF10 signaling controls stomach morphogenesis. Dev Biol 303:295-310. CrossRef Medline

Pencea V, Bingaman KD, Wiegand SJ, Luskin MB (2001) Infusion of brainderived neurotrophic factor into the lateral ventricle of the adult rat leads to new neurons in the parenchyma of the striatum, septum, thalamus, and hypothalamus. J Neurosci 21:6706-6717. Medline

Pérez-Martín M, Cifuentes M, Grondona JM, López-Avalos MD, GómezPinedo U, García-Verdugo JM, Fernández-Llebrez P (2010) IGF-I stimulates neurogenesis in the hypothalamus of adult rats. Eur J Neurosci 31:1533-1548. Medline
Pierce AA, Xu AW (2010) De novo neurogenesis in adult hypothalamus as a compensatory mechanism to regulate energy balance. J Neurosci 30:723730. CrossRef Medline

Rodríguez EM, Blázquez JL, Pastor FE, Peláez B, Peña P (2005) Hypothalamic tanycytes: a key component of brain-endocrine interaction. Int Rev Cytol 247:89-164. CrossRef Medline

Sahara S, O'Leary DD (2009) Fgf10 regulates transition period of cortical stem cell differentiation to radial glia controlling generation of neurons and basal progenitors. Neuron 63:48-62. CrossRef Medline

Shimada M, Nakamura T (1973) Time of neuron origin in mouse hypothalamic nuclei. Exp Neurol 41:163-173. CrossRef Medline

Terauchi A, Johnson-Venkatesh EM, Toth AB, Javed D, Sutton MA, Umemori H (2010) Distinct FGFs promote differentiation of excitatory and inhibitory synapses. Nature 465:783-787. CrossRef Medline

Toyoda R, Assimacopoulos S, Wilcoxon J, Taylor A, Feldman P, SuzukiHirano A, Shimogori T, Grove EA (2010) FGF8 acts as a classic diffusible morphogen to pattern the neocortex. Development 137:3439-3448. CrossRef Medline

Xu Y, Tamamaki N, Noda T, Kimura K, Itokazu Y, Matsumoto N, Dezawa M, Ide C (2005) Neurogenesis in the ependymal layer of the adult rat 3rd ventricle. Exp Neurol 192:251-264. CrossRef Medline

Yokohama-Tamaki T, Ohshima H, Fujiwara N, Takada Y, Ichimori Y, Wakisaka S, Ohuchi H, Harada H (2006) Cessation of Fgf10 signaling, resulting in a defective dental epithelial stem cell compartment, leads to the transition from crown to root formation. Development 133:1359-1366. CrossRef Medline

Zhang X, Ibrahimi OA, Olsen SK, Umemori H, Mohammadi M, Ornitz DM (2006) Receptor specificity of the fibroblast growth factor family. The complete mammalian FGF family. J Biol Chem 281:15694-15700. CrossRef Medline

Zhao C, Deng W, Gage FH (2008) Mechanisms and functional implications of adult neurogenesis. Cell 132:645-660. CrossRef Medline 